\title{
Overview of Contract Interpretation in Investment Treaty Arbitration
}

This chapter summarises empirical observations on contract interpretation in investment treaty arbitration. By focusing on three basic questions of 'what', 'when' and 'how', it provides an overview of interpretative materials, interpretative occasions, applicable procedural frameworks and interpretative patterns.

The chapter opens with the elucidation of what kind of contracts and contractual provisions trigger tribunals' interpretative efforts. This is an important starting point for understanding the composition of interpretative material. Because contracts are not, as a rule, reproduced in awards or elsewhere in full, ${ }^{1}$ their content is re-construed on the basis of the parties' submissions and tribunals' analyses as presented in the text of awards. This means that the work largely follows characterisations adopted by treaty-based tribunals.

The chapter further proceeds to clarify the interpretative occasions, or when treaty-based tribunals have to ascertain the content of contractual provisions. The focus turns to when contracts become relevant for decisions on jurisdiction and merits in investment treaty arbitration and how this specific perspective may impact the tribunals' assessment of the content of contractual provisions. Before illustrating contract interpretation under each of the interpretative occasions, the chapter gives a brief explanation of their regulation in international investment law. This rather brief departure from a purely empirical summary provides an indispensable context for the proper understanding of the reasons governing why treaty-based tribunals need to ascertain the content of contractual provisions and which questions drive their interpretative efforts.

An overview of the applicable procedural framework under which treatybased tribunals act when they ascertain the content of contractual provisions follows the part on interpretative occasions. The chapter lists the most used

1 Occasionally, the entire texts of settlement agreements are accessible. For instance, the full texts of the settlement agreement is recorded in the consent award in Joseph Charles Lemirev. Ukraine, ICSID Case No. АRB (AF)/98/1 and subsequently discussed in Joseph Charles Lemire v. Ukraine, ICSID Case No. ARB/o6/18; a settlement agreement dated 15 June 2014 is publicly available in Lao Holdings N.V. v. Lao People's Democratic Republic, ICSID Case No. ARB(AF)/ $12 / 6$. 
arbitration rules and, where relevant, seats in cases with elements of contract interpretation. This is an indispensable part for further analysis of tribunals' power to interpret contracts in Chapter 4 and a theoretical framework suggested for contract interpretation in investment treaty arbitration in Chapter 5 .

Observations of the patterns which treaty-based tribunals choose for ascertaining the content of contractual provisions conclude the chapter. The book inquires as to whether a classical approach that advocates the role of national law applicable to a contract as a proper framework for contract interpretation in fact informs the efforts of treaty-based tribunals in regard to ascertaining the content of contractual provisions.

\subsection{Interpretative Material: Contracts and Contractual Provisions}

To give an initial account of interpretative material, one has to characterise it as rather detailed agreements concluded between sophisticated parties ${ }^{2}$ and put in writing. ${ }^{3}$ Rarely are the contractual texts internally contradictory or ambiguous. ${ }^{4}$ On most occasions, treaty-based tribunals need to interpret contracts because of newly appeared circumstances.

2 What is meant here is that the contracting parties either act in full understanding of contractual terms, or it is reasonable to conclude that they understand all the intricacies of their deal. Sometimes tribunals even emphasise the level of detail of the contracts in question. For instance, in Suez, Sociedad General de Aguas de Barcelona, S.A. and Vivendi Universal, S.A. v. Argentine Republic, the tribunal described the Concession Contract as 'a lengthy and detailed document of 129 pages' - see Suez, Sociedad General de Aguas de Barcelona, S.A. and Vivendi Universal, S.A. v. Argentine Republic, ICSID Case No. ARB/o3/19, Decision on Liability, 30 July 2010, para. 98 .

3 Treaty-based tribunals are generally hesitant to affirm oral undertakings as part of a contract. See, for instance, Joseph Charles Lemire v. Ukraine, ICSID Case No. ARB / $6 / 18$, in which the tribunal did not accept the claimant's affirmation that the state undertook certain obligations orally over the course of negotiations of a settlement agreement - Joseph Charles Lemire v. Ukraine, ICSID Case No. ARB/o6/18, Decision on Jurisdiction and Liability dated 14 January 2010, para. 115. See also a critical discussion of oral 'Treuhand agreements' under German law in Peter Franz Vocklinghaus v. Czech Republic, Award dated 19 September 2011, para. $155^{-159}$.

4 Ambiguities intrinsic to the contractual wording sometimes may occur. By way of illustration, in Sergei Paushok, CJSC Golden East Company and CJSC Vostokneftegaz Company $v$. The Government of Mongolia, the tribunal expressly noted that certain provisions in Safe Custody/Sale and Purchase of Precious Metal Agreement 'could certainly have been drafted more clearly' - Sergei Paushok, CJSC Golden East Company and CJSC Vostokneftegaz Company v. The Government of Mongolia, Award on Jurisdiction and Liability dated 28 April 2011, para. 544 . 
The above line of description brings no surprise for a dispute resolution mechanism engaging with large-scale investments. What might be less obvious is the fact that only on some occasions are the parties to a contract and the parties to a treaty-based dispute absolutely identical. ${ }^{5}$ On most occasions, the parties to a contract merely retain certain proximity to the parties to a treaty-based dispute. Among them, one can distinguish contracts concluded between a foreign investor as a claimant and a broad range of state-related entities that are not formally respondents in investment treaty arbitration (a ministry or other public authority, a state enterprise, or a state-owned organisation). ${ }^{6}$ One can also observe contracts concluded between a claimant and a third party. ${ }^{7}$ Occasionally, one comes across contracts concluded between the respondent and companies connected with the claimant. ${ }^{8}$ Finally, even contracts concluded between the parties, none of which are formally a party to treaty-based disputes, may also appear as objects to be ascertained in investment treaty arbitration. ${ }^{9}$

While not necessarily between the immediate parties to a treaty-based dispute, the predominant number of ascertained contracts are discussed as being either an investment contract or an investment. ${ }^{10}$ Some of these

For instance, a concession agreement in CCL v. Republic of Kazakhstan, scc Case No.122/2001, Jurisdictional Award dated 1 January 2003, p. 124; a concession agreement in Suez, Sociedad General de Aguas de Barcelona, S.A. and Vivendi Universal, S.A. v. The Argentine Republic, ICSID Case No. АRB/o3/19, Decision on Liability dated 30 July 2010, para. 98; a settlement agreement in Joseph Charles Lemire v. Ukraine, ICsID Case No. ARB $/ 06 / 18$, Decision on Jurisdiction and Liability dated 14 January 2010, para. 33.

6 Forinstance, William Nagelv. The CzechRepublic, scc CaseNo. 049/2002, Final Award, 9 September 2003, para. 1-15; Alpha Projektholding GmbHv. Ukraine, ICSID Case No. ARB /o7/16, Award dated 8 November 2010 para. 56-95; Inmaris Perestroika Sailing Maritime Services GmbH and Others v. Ukraine, ICSID Case No. ARB/o8/8 Award dated 1 March 2012, p. 2 [of the electronic file]; Bosh International, Inc and B\&P Ltd Foreign Investments Enterprise v. Ukraine, ICSID Case No. ARB/o8/11, Award dated 25 October 2012, para. 39.

7 For instance, Gemplus S.A., SLP S.A., Gemplus Industrial S.A. de C.V.v. The United Mexican States, Award dated 16 June 2010, para. 5-28; Talsud S.A. v. The United Mexican States, ICSID Case No. ARB(AF)/o4/4, Award dated 16 June 2010, para. 5-28; Fraport AG Frankfurt Airport Services Worldwide v. Republic of the Philippines, ICSID Case No. ARB $/ 11 / 12$, Award dated 10 December 2014, para. 126.

8 For instance, Burlington Resources Inc. v. Republic of Ecuador, ICSID Case No. ARB/o8/5, Decision on Jurisdiction dated 2 June 2010, para. 14.

9 For instance, Ron Fuchsv. The Republic of Georgia, ICSID Case No. ARB/o7/15, Award dated 3 March 2010, para. 77; Ioannis Kardassopoulos v. The Republic of Georgia, ICsID Case No. ARB/05/18, Award dated 3 March 2010, para. 77 .

10 For instance, Inmaris Perestroika Sailing Maritime Services GmbH and Others $v$. Ukraine, ICSID Case No. ARB/o8/8 Award dated 1 March 2012 para. $5^{2}$ and onward; Noble Energy, Inc. and Machalapower Cia. Ltda. v. The Republic of Ecuador and Consejo Nacional de Electricidad, ICSID Case No. ARB/05/12, Decision on Jurisdiction dated 5 March 2008, para. 
contracts may have a very strong public law element and, as a result, a lessened levels of party autonomy. ${ }^{11}$ There are also investment contracts which are hardly discernible from what is typically referred to as commercial or business contracts, with equal bargaining forces exercised by the parties. ${ }^{12}$ Some well-known standard contract forms, which are well used in ordinary business contexts, such as the FIDIC form for construction, ${ }^{13}$ may necessitate interpretation in investment treaty arbitration as well..$^{14}$ Finally, tribunals

199-203; GEA Group Aktiengesellschaft v. Ukraine, ICSID Case No. AR B/o8/16, Award dated 31 March 2011, para. 145-164; Malaysian Historical Salvors, SDN, BHD v. The Government of Malaysia, ICSID Case No. ARB/05/10, Award on Jurisdiction dated 17 May 2007, para. 46-47, 107-146 (rejecting that the contract for the location and salvage of a British vessel's cargo sank in 1817 and a subsequent contract concerning the auction of potentially recovered items was an investment); Decision on the Application for Annulment dated 16 April 2009, para. 56-82 (annulling award because of a disagreement with the findings that a contract did not constitute an investment).

11 The administrative law element is particularly noticeable in concession agreements and various types of specific licence agreements. See, for instance, a discussion of the role of national administrative law in public contracts in the context of investment treaty arbitration in Azurix Corp. v. The Argentine Republic (I), ICSID Case No. ARB/o1/12, Award dated 14 July 2006, para. 54, 62, 29o; Decision on the Application for Annulment of the Argentine Republic dated 1 September 2009, para. 134 (f). See also Enron Creditors Recovery Corporation (formerly Enron Corporation) and Ponderosa Assets, L.P. v. Argentine Republic, ICSID Case No. ARB/o1/3, Award dated 22 May 2007, para. 220.

12 Among classical commercial contracts which were recognised as investment contracts, one can name, for instance, the hedging agreement involving Deutsche Bank AG in Deutsche Bank AG v. Democratic Socialist Republic of Sri Lanka, ICSID Case No. ARB/og/ 2, Award dated $3_{1}$ October 2012 para. 12-14. It is acknowledged here that in investment treaty arbitration the word 'commercial' is also used in a somewhat different context to identify a contract which does not bear the features of an investment contract in terms of the substantial duration, assumption of investment risk and contribution to the economy of the host state. Subsequent chapters deal with a narrow meaning of investment contract in more detail. This section refers to 'commercial' as a commonly used broad denominator to distinguish a contract concluded in the course of a business activity from consumer contracts and other activities unconnected to business contracts between individuals. It is not uncommon for scholarship to address contract interpretation precisely from the perspective of the interpretation of commercial contracts - see, for instance, Amund Bjøranger Tørum, Interpretation of Commercial Contracts (Universitetsforlag 2019); Mattias Hedwall, Tolkning av Komersiella Avtal (Juristfölaget 1994).

13 'FIDIC' is an abbreviation for the French name for the International Federation of Consulting Engineers, an organisation created in 1913 which became renowned for its standard contract forms for national and international construction - FIDIC official website <http://fidic.org/history > accessed 25 June 2021.

14 Bayindir Insaat Turizm Ticaret Ve Sanayi A.S. v. Islamic Republic of Pakistan, ICsid Case No. ARB/o3/29, Decision on Jurisdiction, 14 November 2005, para. 14-15. 
may also need to interpret contracts that are not investment contracts per $s e^{15}$

In terms of the character of contractual undertakings, the contracts that appear in investment treaty arbitration are typically bilateral ${ }^{16}$ or synallagmatic contracts, in which each of the parties makes an enforceable promise. Some of these contracts have clear features of relational contracts, ${ }^{17}$ anticipating not merely an exchange between the parties but rather a relationship directed at achieving common goals. These contracts impose an expectation of a particular level of cooperation, communication and trust between the parties at various stages of contract performance, which may be adequately illustrated by construction contracts. ${ }^{18}$ These contracts may have rather open-ended provisions on renegotiations and adjustments to keep contractual relations up to the stage of the current development. ${ }^{19}$ On their duration, the contracts may be distinguished between merely transactional or singular contracts, ${ }^{20}$ contracts of medium duration up to 7 years $^{21}$ and significantly long contracts spanning up to dozens of

15 Daimler Financial Services AGv. Argentine Republic, ICSID Case No. ARB/o5/1, Award dated 22 August 2012, para. 146-153; MNSS B.V. and Recupero Credito Acciaio N.V. v. Montenegro, ICSID Case No. ARB(AF)/12/8, Award dated 4 May 2016, para. 158-159, 164.

16 Even a donation in Reinhard Unglaube v. Republic of Costa Rica was bilateral where a foreign investor donated some land plots whereas the state agreed 'not to build any structures on the donated land and to inform administrative authorities of the Municipality of Santa Cruz and other authorities of its approval of the modified Project plan' - see Reinhard Unglaube v. Republic of Costa Rica, ICSID Case No. ARB/og/2O, Award, 16 May 2012, para. 51.

17 On relational contracts, see Melvin A Eisenberg, 'Why There Is No Law of Relational Contracts' (1999) 94 (3) Northwestern University Law Review 8o5.

18 On construction contracts as relational contracts, see Sai On Cheung and others, 'How Relational Are Construction Contracts?' (2006) 132 (1) Journal of Professional Issues in Engineering Education and Practice 48.

19 One may even find a kind of definition for relational contracts in investment treaty arbitration in AWG Group Ltd. v. The Argentine Republic, where the tribunal explained an undertaking between the parties to the concession on 'fluid relationship'- see AWG Group Ltd. v. The Argentine Republic, Award dated 9 April 2015, para. 43.

$20 \quad$ MNSS B.V. and Recupero Credito Acciaio N.V.v. Montenegro, ICSID Case No. ARB(AF)/12/8, Award dated 4 May 2016, para. 158-159.

21 A contract with a five-year duration, renewed automatically if neither party objects in writing to the renewal appears to be mentioned in SGS Société Générale de Surveillance S.A. v. Islamic Republic of Pakistan, ICSID Case No. ARB/o1/13, Decision of the Tribunal on Objections to Jurisdiction dated 6 August 2003, para. 14; a contract of three-year duration - in SGS Société Générale de Surveillance S.A. v. The Republic of Paraguay, ICsid Case No. ARB/07/29, Decision on Jurisdiction dated 12 February 2010, para. 27; a contract of seven-year duration - in Accession Mezzanine Capital L.P. and Danubius Kereskedöház Vagyonkezelö Zrt. v. Hungary, ICSID Case No. ARB/12/3, Award, 17 April 2015, para. 37. 
years. $^{22}$

In terms of their subject matter and as understood from the description already given, the contracts which treaty-based tribunals have to ascertain are from a rather diverse group ${ }^{23}$ that includes (in alphabetical order):

- bareboat charters; ${ }^{24}$

- concession agreements:

- concession agreement for the operation of the national vehicle registry; ${ }^{25}$

- concession agreement for the provision of services; ${ }^{26}$

- concession agreement for water and sewage / water distribution services; $^{27}$

- concession agreement for the exploration of natural resources; ${ }^{28}$

22 A concession with a 30-year duration appears in Suez, Sociedad General de Aguas de Barcelona S.A., and InterAguas Servicios Integrales del Agua S.A. v. The Argentine Republic, ICSID Case No. ARB /03/17, Decision on Liability dated 3 O July 2010, para. 212; a concession with a 15-year duration with the possibility of prolongation for another 5 years - in TSA Spectrum de Argentina S.A. v. Argentine Republic, ICSID Case No. ARB/05/5, Award dated 19 December 2008, para. 8; a concession of 15-year duration - in Waste Management, Inc. v. United Mexican States ("Number 2"), Award dated 30 April 2004, para. 46; a concession with a 95-year duration - in National Grid plc v. The Argentine Republic, UnCITRAL, Award dated 3 November 2008, para. 54 .

23 Some of the mentioned types in the list may also fall into other categories. As identified earlier, the description of the contracts largely follows the wording in the awards.

24 Inmaris Perestroika Sailing Maritime Services GmbH and Others v. Ukraine, ICsID Case No. ARB/o8/8, Decision on Jurisdiction dated 8 March 2010, para. 66-88.

25 Gemplus S.A., SLP S.A., Gemplus Industrial S.A. de C.V.v. The United Mexican States, ICSID Case No. ARB $(\mathrm{AF}) / 04 / 3$, Award dated 16 June 2010, para. 4-44; Talsud S.A. v. The United Mexican States, ICSID Case No. ARB(AF)/o4/4, Award dated 16 June 2010, para. 4-44.

26 Information technology services appeared in IBM World Trade Corporation v. República del Ecuador, ICSID Case No. ARB/O2/10, Decision on Jurisdiction and Competence dated 22 December 2003, para. 54-63; operation of a (first) mobile telephony network - in Millicom International Operations B.V. and Sentel GSM SA v. The Republic of Senegal, ICSID Case No. ARB/o8/20, Decision on Jurisdiction of the Arbitral Tribunal dated 16 July 2010, para. 8, 97; services on pre-shipment inspection of imported goods on the basis of which import duties and tax levies were to be calculated - in SGS Société Générale de Surveillance S.A. v. Islamic Republic of Pakistan, ICsid Case No. ARB/o1/13, Decision of the Tribunal on Objections to Jurisdiction dated 6 August 2003, para. 135, 160-161.

27 Azurix Corp. v. The Argentine Republic, ICSID Case No. ARB/o1/12, Award dated 14 July 2006, para. 41, 114-119; Impregilo S.p.A. v. Argentine Republic, ICSID Case No. ARB/o7/17, Award dated 21 June 2011, para. 14-15, 322-323.

28 Oil concession appeared in Chevron Corporation (USA) and Texaco Petroleum Company (USA) v. The Republic of Ecuador, Uncitral, PCA Case No. 34877, Partial Award on the Merits dated 30 March 2010, para. 33, 448-451; oil concession (discussed mostly in the context of the settlement agreement) - in Chevron Corporation and Texaco Petroleum 
- concession agreement for the distribution / supply of electricity; ${ }^{29}$

- concession agreement for construction / construction and operation; ${ }^{30}$

- concession agreement for the operation of pipelines; ${ }^{31}$

- contract on the provision of an integral service for the implementation of immigration control, personal identification and electoral information; ${ }^{32}$

- construction agreement; 33

- credit agreement; ${ }^{34}$

- donation of land plots agreement; 35

- funding agreement (third-party funding); ${ }^{36}$

- electricity purchase agreement ${ }^{37}$;

Company v. The Republic of Ecuador (II), PCA Case No. 2009-23, Third Interim Award on Jurisdiction and Admissibility dated 27 February 2012, para. 3.7-3.12.

29 EDF International S.A., SAUR International S.A. and León Participaciones Argentinas S.A. v. Argentine Republic, ICSID Case No. ARB/o3/23, Award dated 11 June 2012, para. 5o, 943-969; National Grid plc v. The Argentine Republic, Award dated 3 November 2008, para. $54-58,117-124$.

30 A concession on construction and operation of a new international passenger airport terminal l ("Terminal 3") in Manila appeared in Fraport AG Frankfurt Airport Services Worldwide v. Republic of the Philippines, ICSID Case No. ARB/11/12, Award dated 10 December 2014, para. $5^{-10}$ (the tribunal more extensively referred in the analysis to another contract - pooling agreement; see also below); a concession on construction and operation of a toll highway in Bangkok - in Werner Schneider, acting in his capacity as insolvency administrator of Walter Bau Ag (In Liquidation) v. Kingdom of Thailand, UNCITRAL, Award dated 1 July 2009, para. 2.35-2.40, 7.13-7.19.

31 Ron Fuchs v. The Republic of Georgia, ICSID Case No. ARB/o7/15, Award, 3 March 2010, para. 94-103, 318-322, 331-341; Ioannis Kardassopoulos $v$. The Republic of Georgia, ICSID Case No. ARB/o5/18, Award, 3 March 2010, para. 94-103, 318-322, 331-341.

32 Siemens A.G. v. The Argentine Republic, ICSID Case No. ARB/o2/8, Decision on Jurisdiction dated 3 August 2004, para. 23-25, 174-180, Award dated 6 February 2007, para. 128-150.

33 Bayindir Insaat Turizm Ticaret Ve Sanayi A.S. v. Islamic Republic of Pakistan, ICsid Case No. ARB/o3/29, Award dated 27 August 2009, para. 13-22, 252-356; Garanti Koza LLP v. Turkmenistan, ICSID Case No. ARB/11/20, Award dated 19 December 2016, para. 4-5, 331-337, 346-354.

34 Waste Management, Inc. v. United Mexican States ("Number 2"), ICsID Case No. ARB(AF)/ oo/3, Award dated 30 April 2004, para. 50-51, 102-103, 118-129.

35 Marion Unglaube v. Republic of Costa Rica, ICsid Case No. ARB / o8/1, Award dated 16 May 2012, para. 49-59; 170-197; Reinhard Unglaube v. Republic of Costa Rica, ICsid Case No. ARB/o9/20, Award dated 16 May 2012, para. 49-59; 170-197.

36 Teinver S.A., Transportes de Cercanías S.A. and Autobuses Urbanos del Sur S.A. v. The Argentine Republic, ICsid Case No. ARB/o9/1; Decision on Jurisdiction dated 21 December 2012, para. 239-259; Award dated 21 July 2017, para. 224-233.

37 Mercer International Inc. v. Government of Canada, ICSID Case No. ARB (AF)/12/3, Award dated 6 March 2018, para. $3.82-3.85$. 
- farmout agreement; 38

- joint venture agreement and partnership; ${ }^{39}$

- hedging agreement; 40

- lease agreement; ${ }^{41}$

- licence agreement; ${ }^{42}$

- loan agreement ${ }^{43}$;

- mine operation contract; ${ }^{44}$

- offtake agreement; 45

- pledge agreement; ${ }^{46}$

38 Occidental Petroleum Corporation and Occidental Exploration and Production Company v. The Republic of Ecuador (II), ICSID Case No. ARB/o6/11, Award dated 5 October 2012, para. 92, 127-134, 331, 386 .

39 Ron Fuchs v. The Republic of Georgia, ICSID Case No. ARB/07/15, Award dated 3 March 2010, para. 318-330; Ioannis Kardassopoulos v. The Republic of Georgia, ICsid Case No. ARB/ 05/18, Award dated 3 March 2010, para. 318-330; Gustav F W Hamester GmbH \& Co $K G$ v. Republic of Ghana, ICSID Case No. ARB / o7/24, Award dated 18June 2010, para. 22-27, 263-266; EDF (Services) Limited v. Republic of Romania, ICsID Case No. ARB/ o5/13, Award dated 8 October 2009, para. 47-64; 245-246; Société Générale In respect of DR Energy Holdings Limited and Empresa Distribuidora de Electricidad del Este, S.A. v. The Dominican Republic, LCiA Case No. UN 7927, Award on Preliminary Objections to Jurisdiction dated 19 September 2008, para. 46-47.

40 Deutsche Bank AG v. Democratic Socialist Republic of Sri Lanka, ICsid Case No. ARB/og/2, Award dated 31 October 2012, para. 12-36, 323-347.

41 MamidoilJetoil Greek Petroleum Products Societe S.A. v. Republic of Albania, ICsID Case No. ARB $/ 11 / 24$, Award dated 30 March 2015, para. 81, 648; Generation Ukraine, Inc. v. Ukraine, ICSID Case No. ARB / oo/9, Award dated 16 September 2003 para. 18.23-18.42; Lee John Beck and Central Asian Development Corporation v. Kyrgyz Republic Award dated 13 November 2013, p. 2-3, 26, 37; Flemingo DutyFree Shop Private Limited v. the Republic of Poland, Award dated 12 August 2016, para. 6o-82, 546-56o.

42 Enron CorporationandPonderosa Assets, L.P.v.Argentine Republic, ICsid CaseNo. ARB/o1/3, Decision on Jurisdiction (Ancillary Claim), 2 August 2004, para. 23, 47-52, Award dated 22 May 2007, para. 43, 151-155; Ulysseas, Inc. v. The Republic of Ecuador, UNCITRAL, Interim Award dated 28 September 2010, para. 67-72, 149-163.

43 Ceskoslovenska Obchodni Banka, A.S. v. The Slovak Republic, ICSID Case No. ARB/97/4, Award dated 29 December 2004, para. 30-31, 239-257, 272-278, 303-313; (loan and security agreement) British Caribbean Bank Limited v. The Government of Belize, PCA Case No. 2010-18, Award dated 19 December 2014, para. 168-175.

44 Crystallex International Corporation v. Bolivarian Republic of Venezuela, ICsid Case No. $\operatorname{ARB}(\mathrm{AF}) / 11 / 2$, Award dated 4 April 2016, para. 18-20, 205, 481-483, 698-700.

45 Koch Minerals Sàrl and Koch Nitrogen International Sàrlv. Bolivarian Republic of Venezuela, ICSID Case No. ARB/11/19, Award dated 30 October 2017, para. 2.15, 4.11-4.17, 6.58-6.71, 7.41-7.51.

46 Hassan Awdi, Enterprise Business Consultants, Inc. and Alfa El Corporation v. Romania, ICSID Case No. ARB B/10/13, Award dated 2 March 2015, para. 58-60, 220-221, 368-383. 
- pooling agreement (corporate shareholders agree that their shares will be voted as a unit); $; 7$

- privatisation agreement; ${ }^{48}$

- sale contract; ${ }^{49}$

- service agreement; 50

- settlement agreement; 51

- share purchase agreement; ${ }^{2}$

- trust contract; 53

- usufruct contract; 54

- and various others. ${ }^{55}$

47 Fraport AG Frankfurt Airport Services Worldwide v. Republic of the Philippines (II), ICSID Case No. ARB/11/12, Award dated 10 December 2014, para. 113-114, 442-468.

48 Plama Consortium Limited v. Republic of Bulgaria, ICSID Case No. ARB/o3/24, Award dated 27 August 2008, para. 84, 113-114; Vincent J. Ryan, Schooner Capital LLC, and Atlantic Investment Partners LLC v. Republic of Poland, ICsid Case No. ARB $(\mathrm{AF}) / 11 / 3$, Award dated 24 November 2015, para. 53-55, 75-83, 254-258; Hassan Awdi, Enterprise Business Consultants, Inc. and Alfa El Corporation v. Romania, ICSID Case No. ARB/10/13, Award dated 2 March 2015, para. 368-383; (a transfer agreement of shareholdings to consortiums in the course of privatisation) Telefónica S.A. v. The Argentine Republic, ICsid Case No. ARB / O3/20, Decision of the Tribunal on Objections to Jurisdiction, 25 May 2006, para. 87 .

49 A sale contract of land in a touristic area in Egypt appeared in Waguih Elie George Siag and Clorinda Vecchi v. Arab Republic of Egypt, ICSID Case No. ARB/05/15, Award dated 1 June 2009, para. 507-510, 528-529, 577-584.

50 A contract on provision of 'know-how' to a wine company appeared in Luigiterzo Bosca v. Lithuania, Award dated 17 May 2013, para. 166-178; a rental services contract appeared in Karkey Karadeniz Elektrik Uretim A.S. v. Islamic Republic of Pakistan, ICsID Case No. ARB / 13/1, Award dated 22 August 2017, para. 690-698.

51 Joseph Charles Lemire v. Ukraine, ICSID Case No. ARB/o6/18, Decision on Jurisdiction and Liability dated 14 January 2010, para. 114-115; William Nagel v. The Czech Republic, sCC Case No. 049/2002, Final Award dated 9 September 2003, para. 225-244; Noble Ventures, Inc. v. Romania, ICSID Case No. ARB / o1/11, Award dated 12 October 2005, para. 198-202.

$5^{2}$ Swisslion DOO Skopje v. The former Yugoslav Republic of Macedonia, ICSID Case No. ARB/ o9/16, Award dated 6 July 2012, para. 180-181.

53 Empresa Electrica del Ecuador, Inc. (EMELEC) v. Republic of Ecuador, ICSID Case No. ARB/ 05/9, Award dated 2 June 20o9, para. 53, 86 and onward.

54 Railroad Development Corporation ( $R D C)$ v. Republic of Guatemala, ICSID Case No. ARB/ 07/23, Award dated 29 June 2012, para. 82-84.

55 For instance, in the consolidated arbitration, Marion Unglaube v. Republic of Costa Rica and Reinhard Unglaube v. Republic of Costa Rica, a tribunal, in addition to a donation agreement in exchange for certain undertakings in relation to an investment project, also had to deal with a so-called 'road map agreement' as a specific agreement evidencing undertakings on the part of the state to enable an investment project - see Marion Unglaube v. Republic of Costa Rica, ICSID Case No. ARB/o8/1, Award dated 16 May 2012, para. 75-76; 170; 185-191; 250 and Reinhard Unglaube v. Republic of Costa Rica, ICSID Case No. ARB/og/2o, Award dated 16 May 2012, para. 75-76; 170; 185-191; 25o. Another 
When approaching these contracts, treaty-based tribunals have to ascertain a broad range of contractual provisions. These provisions may be summarised via commonly used categories listed below in alphabetical order:

- choice of law; 56

- currency adjustment; ${ }^{57}$

- dispute resolution; ${ }^{58}$

- exclusivity; 59

- force majeure; ${ }^{60}$

- interpretative provisions; 61

interesting example represents a contract for the location and salvage of a British vessel's cargo which sank in 1817, and a contract concerning the auction of potentially recovered items in Malaysian Historical Salvors, SDN, BHD v. Malaysia, ICSID Case No. ARB/ o5/10. In the case, the sole arbitrator denied jurisdiction, and the annulment committee subsequently annulled the award, disagreeing with the qualification of the contract on salvage as not being an investment contract - see Malaysian Historical Salvors, SDN, BHD v. Malaysia, ICSID Case No. ARB/o5/10, Award on Jurisdiction dated 17 May 2007, para. 107-146; Decision on the Application for Annulment dated 16 April 20o9, para. 6o and onward.

56 Daimler Financial Services AG v. The Argentine Republic, ICSID Case No. ARB/O5/1, Award dated 22 August 2012, para. 116-117, 124-125, 133, 146.

57 National Grid plc v. The Argentine Republic, UnCitral, Award dated 3 November 2007, para. 116-124; EDF International S.A., SAUR International S.A. and León Participaciones Argentinas S.A.v. Argentine Republic, ICSID Case No. ARB/o3/23, Award dated 11 June 2012, para. 943-969.

58 Compañia de Aguas del Aconquija S.A. and Vivendi Universal v. Argentine Republic, ICSID Case No. ARB/97/3, Award dated 21 November 20oo, para. 53-54; SGS Société Générale de Surveillance S.A. v. Republic of Paraguay, ICSID Case No. ARB/o7/29, Decision on Jurisdiction dated 12 February 2010, para. 34, 129-138; TSA Spectrum de Argentina S.A. v. The Argentine Republic, ICsid Case No. ARB/05/5, Award dated 19 December 2008 para. 56-66. See also Jeffrey M Hertzfeld and Barton Legum, 'Pre-Dispute Waivers of Investment Treaty Arbitration: A Practical Approach' in Kaj Hobér and others (eds), Between East and West: Essays in Honour of Ulf Franke (Juris Publishing 2010) 183; Ole Spiermann, 'Individual Rights, State Interests and the Power to Waive ICSID Jurisdiction under Bilateral Investment Treaties' (2004) 20 (2) Arbitration International 179; S I Strong, 'Contractual Waivers of Investment Arbitration:Wa(i)ve of the Future?' (2014) 29 (3) ICSID Review 69o; Emmanuel Gaillard, 'Investment Treaty Arbitration and Jurisdiction over Contract Claims - the sGs Cases Considered' in Todd Weiler (ed), International Law and Arbitration: Leading Cases from the ICSID, NAFTA, Bilateral Treaties and Customary International Law (Cameron May 2005) 325-346.

59 Mr. Franck Charles Arif v. Republic of Moldova, ICsid Case No. ARB/11/23, Award dated 8 April 2013, para. $55^{-}-555$.

6o Unión Fenosa Gas, S.A. v. Arab Republic of Egypt, ICsid Case No. Arb/14/4, Award dated $3_{1}$ August 2018, para. 9.57-9.84.

61 Joseph Charles Lemire v. Ukraine, ICSID Case No. ARB/o6/18, Decision on Jurisdiction and Liability dated 14 January 2010, para. 108-115. 
- limitation of liability or waiver of liability clauses; ${ }^{62}$

- linguistic discrepancy; ${ }^{63}$

- notification; ${ }^{64}$

- penalty; 65

- preamble; $; 6$

- price; ${ }^{67}$

- renegotiations; $; 8$

- stabilisation clauses and economic equilibrium;69

- termination clauses; ${ }^{70}$

62 Toto Costruzioni Generali S.p.A. v. The Republic of Lebanon, ICSID Case No. ARB/o7/12, Award dated 7 June 2012 para. 65-85. See also Inna Uchkunova, 'Where Both Worlds Meet: Contractual Waiver of Liability and the Contract-Treaty Divide' $(2012)<\mathrm{http} / /$ kluwerarbitrationblog.com/2012/11/o8/where-both-worlds-meet-contractual-waiver-of-liability-and-the-contract-treaty-divide/> accessed 25 June 2021.

63 Caratube International Oil Company LLP and Devincci Salah Hourani v. Republic of Kazakhstan, ICSID Case No. ARB/13/13, Award dated 27 September 2017, para. 601-604.

64 Bayindir Insaat Turizm Ticaret Ve Sanayi A.S. v. Islamic Republic of Pakistan, ICsid Case No. ARB/o3/29, Award, 27 August 2009, para. 252-258.

65 Duke Energy Electroquil Partners \& Electroquil S.A. v. Republic of Ecuador, ICSID Case No. ARB/04/19, Award dated 18 August 2008, para. 138-144; Karkey Karadeniz Elektrik Uretim A.S. v. Islamic Republic of Pakistan, ICSID Case No. ARB/13/1, Award dated 22 August 2017, para. 686-698 (the tribunal ultimately found that the provision was not a penalty clause but rather a sort of liquidated damages).

66 Eureko B.V. v. Republic of Poland, Partial Award dated 19 August 2005, para. 152-156; Empresa Eléctrica del Ecuador, Inc. v. Republic of Ecuador, ICSID Case No. ARB/05/9, Award dated 2 June 2009, para. 116; Chevron Corporation (USA) and Texaco Petroleum Company (USA) v. The Republic of Ecuador, UnCITRAL, PCA Case No. 34877, Partial Award on the Merits dated 30 March 2010, para. 440-442.

67 Nykomb Synergetics Technology Holding AB v. The Republic of Latvia, SCC, Award, 16 December 2003, para. 3.7; Gustav F W Hamester GmbH \& Co KG v. Republic of Ghana, ICSID Case No. ARB/O7/24, Award dated 18 June 2010, para 212-218.

68 Occidental Exploration and Production Companyv. The Republic of Ecuador, LCIA Case No. UN3467, Final Award dated 1 July 2004, para. 35; 111-115.

69 Burlington Resources Inc. v. Republic of Ecuador, ICsID Case No. ARB/o8/5, Decision on Liability, 14 December 2014, para. 21, 316-335; Ron Fuchs v. The Republic of Georgia, ICSID Case No. ARB/o7/15, Award dated 3 March 2010, para. 479-485; Ioannis Kardassopoulos v. The Republic of Georgia, ICsid Case No. ARB/o5/18; Award dated 3 March 2010, para. 479-485; Ron Fuchs v. The Republic of Georgia, ICSID Case No. ARB/o7/15, Award dated 3 March 2010, para. 479-485. CMS Gas Transmission Company v. The Argentine Republic, ICSID Case No. ARB/o1/8, Award dated 12 May 2005, para. 151, 302.

$70 \quad$ Vigotop Limited v. Hungary, ICSID Case No. ARB/11/22, Award, 1 October 2014, para. 516519; Mr. Kristian Almås and Mr. Geir Almås v. The Republic of Poland, PCA Case No 2015-13, Award, 27 June 2016, para. 251; Flemingo DutyFree Shop Private Limited v. the Republic of Poland, Award dated 12 August 2016, para. 538-56o. 
- tax modification clauses; ${ }^{71}$

- other. ${ }^{72}$

In terms of intensity, some provisions appear with particular frequency. They include various provisions on mutual contractual undertakings between the parties to a contract, provisions on dispute resolution (forum selection clause) in their interrelations with investment treaty arbitration, provisions on stabilisation, economic equilibrium, renegotiations and provisions on contract termination.

\section{Interpretative Occasions}

Contract interpretation purposes, or interpretative occasions, are rather peculiar in investment treaty arbitration. Unlike in contract-based arbitration, ${ }^{73}$ contracts do not receive direct enforcement in investment treaty arbitration. What receives enforcement are the international law obligations which states undertake in relation to foreign investments in IIAs. ${ }^{74}$ On their basis, a foreign investor may attempt to attach international responsibility to a state for violations of treaty provisions ensuring fair and equitable treatment (FET), observance of undertakings (umbrella clause), national treatment, most-favourednation treatment (MFN) and other guarantees, along with an undertaking not

71 Tax modification clauses were discussed as to whether they are a sort of stabilisation clause or merely renegotiation clauses in Burlington Resources Inc. v. Republic of Ecuador, ICSID Case No. ARB/08/5, Decision on Liability dated 14 December 2014, para. 316-335.

72 A specific provision on the assumed nationality of the parties for the purpose of jurisdiction was addressed in Caratube International Oil Company LLP and Devincci Salah Hourani v. Republic of Kazakhstan, ICSID Case No. ARB/13/13, Award, 27 September 2017, para. 27, 6o1-610; provisions on specific undertakings of a broadcaster - in Accession Mezzanine Capital L.P. and Danubius Kereskedöház Vagyonkezelö Zrt. v. Hungary, ICsid Case No. ARB/12/3, Award dated 17 April 2015, para. 80-96; a specific provision so called 'the participation formula' in contracts on exploration and exploitation of oil and gas fields was addressed in Occidental Exploration and Production Company v. The Republic of Ecuador, LCIA Case No. UN3467, Final Award, 1 July 2004, para. 28-34; 105.

73 Contract-based arbitration preceded investment treaty arbitration and continues to flourish throughout its existence. Many contract-based awards in investment disputes between a foreign investor and a state are published at ITALAw $<$ https://www.italaw. com/> accessed 25 June 2021.

74 Appearing first in the 1960-1970s, these treaties have by now substantially multiplied to provide a foundation for a new branch of international investment law and investment treaty arbitration. For a visual illustration of the growth of IIAs over time, see the PITAD database graph at <https://pitad.org/index\#static/illustrations > accessed 25 June 2021. 
to exercise unlawful expropriation. ${ }^{75}$ Tribunals deciding on jurisdiction or assessing the merits of these claims would need to ascertain the content of contractual provisions with which the invoked standards of investment protection may closely engage.

Occasionally, tribunals may need to interpret contracts for other purposes than connected with their protection under international law. Contracts with varying degrees of proximity to investment contracts, such as assignment agreements and share purchase agreements, typically appear in this context. These agreements are viewed less directly in the context of standards of investment protection and are more often ascertained and analysed for deciding on jurisdiction and various questions of procedural character. ${ }^{76}$

The examples below illustrate occasions for contract interpretation in investment treaty arbitration, such as jurisdiction, attribution, expropriation, FET, umbrella clause, national treatment, MFN, and compensation.

\subsubsection{Jurisdiction}

Unlike in contract-based arbitration, jurisdiction of treaty-based tribunals is not based on a single arbitration agreement, but rather on acceptance of an offer to arbitrate in IIAs. The content of the offer and other pre-conditions for instituting the proceedings in investment treaty arbitration vary across treaties. ${ }^{77}$ In regard to subject matter jurisdiction (jurisdiction ratione materiae), the proper parties to the dispute (jurisdiction ratione personae), consent to jurisdiction (jurisdiction ratione voluntatis), temporal jurisdiction (jurisdiction ratione temporis), and issues of claim admissibility ${ }^{78}$ typically cause disagreements in investment treaty arbitration.

Contracts may require interpretation for deciding on jurisdiction ratione materiae, jurisdiction ratione personae, and jurisdiction ratione voluntatis. For

75 For a comprehensive overview of the standards of investment protection, see August Reinisch, Standards of Investment Protection (Oxford University Press 2008).

76 Somewhat exceptionally, settlement agreements may also appear in the context of substantive standards of investment treaty protection - see Joseph Charles Lemire v. Ukraine, ICSID Case No. ARB/o6/18.

77 David A R Williams, 'Jurisdiction and Admissibility' in Peter Muchlinski and others (eds), The Oxford Handbook of International Investment Law (Oxford University Press 2008) 865-931.

78 Issues of admissibility are frequently addressed separately from jurisdiction. This work follows the opinion of Veijo Heiskanen that admissibility is not conceptually that distinct from jurisdiction broadly perceived - Veijo Heiskanen, 'Ménage à Trois? Jurisdiction, Admissibility and Competence in Investment Treaty Arbitration' (2014) 29 (1) ICSID Review, 231, 246. 
instance, tribunals may need to look deeper into the parties' mutual undertakings and their original intent to decide if a contract in question falls into the category of investment contract or investment. ${ }^{79}$ Tribunals may also need to decide on the standing of a claimant because of an alleged claim settlement, ${ }^{80}$ the participation of a third-party funder, ${ }^{81}$ a share transfer or a claim assignment, ${ }^{82}$ etc. When facing a claim based substantially on a contract, treatybased tribunals may need to make a decision as to whether a forum selection clause in the contract operates as a waiver of treaty jurisdiction and an impediment to jurisdiction ratione voluntatis.

The example of Suez, Sociedad General de Aguas de Barcelona S.A., and InterAguas Servicios Integrales del Agua S.A. v. The Argentine Republic ${ }^{83}$ illustrates interpretation in the context of ratione voluntatis. The dispute arose out of an alleged failure on the part of a state to apply agreed adjustments to the tariff calculation that negatively affected a concession for water distribution and wastewater treatment services in the Argentine Province of Santa Fe. The claimant alleged direct and indirect expropriation, FET violation and other violations of standards of investment protection. Because of the state's objections to jurisdiction, the tribunal had to consider the effect of a forum selection clause on its own jurisdiction. A textual verification of the absence of a waiver to treaty jurisdiction became an important component for the tribunal's decision in affirming jurisdiction. The tribunal, in particular, observed:

79 Luigiterzo Bosca v. Lithuania, PCA Case No. 2011-05, Award dated 17 May 2013, para. 166-178; ADC Affiliate Limited and ADC \& ADMC Management Limited $v$. The Republic of Hungary, ICSID Case No. ARB/o3/16, Award dated 2 October 2006, para. 325.

8o Azpetrol International Holdings B.V., Azpetrol Group B.V. and Azpetrol Oil Services Group B.V. v. The Republic of Azerbaijan, ICSID Case No. ARB/o6/15, Award dated 8 September 2009, para. 44-47.

81 Ambiente Ufficio S.p.A. and others (formerly Giordano Alpi and others) v. Argentine Republic, ICsid Case No. ARB/o8/9 Decision on Jurisdiction and Admissibility dated 8 February 2013, para. $273^{-278 .}$

82 Daimler Financial Services AG v. Argentine Republic, ICSID Case No. ARB/05/1, Award dated 22 August 2012, para. 146, 151-153; Talsud S.A. v. The United Mexican States, ICSID Case No. ARB (AF)/o4/4, Award dated 16 June 2010, para. 5-28-5-33; Gemplus S.A., SLP S.A., Gemplus Industrial S.A. de C.V.v. The United Mexican States, ICSID Case No. ARB (AF)/o4/3, Award dated 16 June 2010, para. 5-28-5-33; Vannessa Ventures Ltd. v. Bolivarian Republic of Venezuela, ICSID Case No. ARB(AF)o4/6, Award dated 16 January 2013, para. 121-169; STAD GmbHv. Republic of Bulgaria, UnCITRAL, PCA Case No. 2011-06, Award on Jurisdiction dated 18 July 2013 , para. $272-273$.

83 Suez, Sociedad General de Aguas de Barcelona S.A., and InterAguas Servicios Integrales del Agua S.A. v. The Argentine Republic, ICsID Case No. ARB/o3/17, Decision on Jurisdiction dated 16 May 2006. 
In order to assess the Respondent's jurisdictional objections on this point, one must consider the nature and implications of the dispute settlement clause concluded by APSF ${ }^{84}$ and the Province of Santa Fe. By its terms, the dispute resolution clause covers all controversies arising out of the concession contract. The dispute resolution clause makes no mention of Claimants' rights under the Argentina-France BIT, the Argentina-Spain $B I T$, or their right to seek recourse in arbitration for violation of those rights. In the present case, the Claimants, as they rightly point out, do not allege any violation of their rights under the concession contract. Rather, the basis of their claim is that the Respondent has violated the Claimants' rights under the BITs. BIT claims and contractual claims are two different things. ...

It follows from the above discussion that, contrary to Argentina's argument, the execution of a dispute resolution clause in the concession agreement does not mean that the parties have waived ICSID jurisdiction. Certainly, the execution of a dispute settlement clause, like the one in the Santa Fe concession contract, which makes no reference to the BIT or to the treatment that the BIT guarantees investors, cannot support any inference that such dispute resolution clause is a waiver of the investors' rights under а віт. The Tribunal concludes that the existence of the dispute resolution clause in the concession contract does not preclude the Claimants from bringing the present action. Consequently, Respondent's fourth objection to the ICSID's and this Tribunal's jurisdiction must fail. ${ }^{85}$ [emphasis added]

A closer observation of how tribunals interpret contracts when they decide on jurisdictional issues reveals textual preferences. Tribunals primarily look at whether there is a textual confirmation that a certain claim was assigned, or that a claim was conclusively settled, or a share was transferred, or that a third-party funder has assumed the rights of a claimant, or a forum selection clause evidences a waiver of treaty jurisdiction, etc. In deciding on jurisdiction,

84 APSF, or Aguas Provinciales de Santa Fe S.A., was an original claimant to the dispute. It was a company registered in Argentina that concluded a 30-year concession contract on the control and management of the water distribution and wastewater systems in the 15 urban areas in the Province of Santa Fe. Both other claimants had shares in APSF. The proceedings in relation to APSF were subsequently discontinued for reasons unrelated to a forum selection clause, leaving only two claimants in the proceedings.

85 Suez, Sociedad General de Aguas de Barcelona S.A., and InterAguas Servicios Integrales del Agua S.A. v. The Argentine Republic, ICsID Case No. ARB/o3/17, Decision on Jurisdiction dated 16 May 2006, para. $43-45$. 
tribunals integrate their conclusions on the content of contractual provisions into a complex matrix of decision-making based, as described above, on the numerous factors defined by an applicable IIA.

\subsubsection{Attribution}

A state is responsible for the conduct of its organ or an individual if that conduct is attributable to it. ${ }^{86}$ Findings on attribution cannot be reduced only to observations on factual causality. ${ }^{87}$ The rules of attribution as reflected in the International Law Commission Articles on the Responsibility of States for Internationally Wrongful Acts (ILC Articles) ${ }^{88}$ shall guide the reasoning. ${ }^{89}$ They reflect structural (Article 4), functional (Article 5) and controlling (Article 8) criteria for defining attribution. As there is no requirement on accumulated application of these criteria, satisfaction of one is sufficient for a finding on attribution.

Addressing these criteria, treaty-based tribunals may find some confirmation of attribution in contractual provisions. ${ }^{90}$ It may happen that contracts

86 James Crawford, State Responsibility: The General Part (Cambridge University Press 2013) 112-212; Kaj Hobér, 'State Responsibility and Attribution' in Peter Muchlinski and others (eds), The Oxford Handbook of International Investment Law (Oxford University Press 2008) 550-583; Simon Olleson, 'Attribution in Investment Treaty Arbitration' (2016) 31(2) ICSID Review 457, 457-483.

87 James Crawford, State Responsibility: The General Part (Cambridge University Press 2013) 113 .

88 International Law Commission, 'Report of the International Law Commission on the Work of its Fifty-third Session' (23 April-1 June and 2 July-10 August 2001) A/CN.4/SER.A/ 2001/Add.1 (Part 2), 26-30, available at <https://legal.un.org/ilc/publications/yearbooks/ english/ilc_20o1_v2_p2.pdf > accessed 26 September 2021.

89 Despite wide acceptance, the status of the ILC Articles is 'predicated upon a process of integration into practice, which is inherently uncertain'. - James Crawford, 'Investment Arbitration and the ILC Articles on State Responsibility' (2010) 25(1) ICSID Review 128-129.

9o The Commentary to the ILC Articles explains, for instance: 'It is irrelevant for the purposes of attribution that the conduct of a State organ may be classified as "commercial" or as acta iure gestionis. Of course, the breach by a State of a contract does not as such entail a breach of international law. Something further is required before international law becomes relevant, such as a denial of justice by the courts of the State in proceedings brought by the other contracting party. But the entry into or breach of a contract by a State organ is nonetheless an act of the State for the purposes of article 4, and it might be in certain circumstances amount to an internationally wrongful act.' - International Law Commission, 'Report of the International Law Commission on the Work of its Fifty-third Session' (23 April-1 June and 2 July-10 August 2001) A/CN.4/SER.A/2001/Add.1 (Part 2), available at $<$ https://legal. un.org/ilc/publications/yearbooks/english/ilc_2001_v2_p2.pdf> accessed 26 September 2021. 
reflect on whose behalf a contracting party associated with the state is acting or elucidate motives connected with the exercise of a state function or otherwise point to the state through the rights and obligations of a party associated with a state under a contract. The analysis would be analytically distinct from an inquiry of contractual responsibility. ${ }^{91}$ If a state is found to be a party to a contract concluded with a separate entity, it is because of rules of national law applicable to a contract, not because of attribution. If a state is found to be internationally responsible for certain acts in relation to a contract, it is because of the rules of international law on attribution, not because of national law. ${ }^{92}$ At the same time, the role of contractual provisions for the purpose of the decision on attribution shall not be overstated. Ascertainment of the content of contractual provisions alone would not suffice to establish attribution as the actual conduct attributable to the state would matter most. ${ }^{93}$ Contracts rather play a reconfirming role, albeit occasionally a decisively reconfirming role.

Garanti Koza LLP v. Turkmenistan ${ }^{94}$ serves as a good illustration of a case where a tribunal had to ascertain the content of contractual provisions, among many other aspects, of a treaty claim, for a decision to be made on attribution. The contract on the construction of highway bridges between The State concern 'Turkmenavtoyollary' (TAY) and the Turkish contractor (Garanti Koza LLP) appeared central to the dispute. Affirming that acts of non-performance, and the suspension and subsequent termination of the contract were all attributable to the state directly triggering standards of investment protection, the claimant relied on contractual provisions as part of the overall argumentation on attribution. The respondent opposed this, insisting that all attempts to rely on contractual provisions looked more like an attempt to attach responsibility

91 James Crawford, 'Investment Arbitration and the ILC Articles on State Responsibility' (2010) 25(1) ICSID Review 127, 134.

92 Simon Olleson, 'Attribution in Investment Treaty Arbitration' (2016) 31(2) ICsID Review 457, 465; Kaj Hobér, 'State Responsibility and Attribution' in Peter Muchlinski and others (eds), The Oxford Handbook of International Investment Law (Oxford University Press 2008) 581-582; Campbell McLachlan and others, International Investment Arbitration: Substantive Principles (2nd edn, Oxford University Press 2017) 139-140 (see also fn 210 on page 319 with some critics of Bosh International Inc and B\&P Ltd Foreign Investments Enterprise v. Ukraine, Award dated 25 October 2012, para. 246).

93 See, for instance, the reasoning of the tribunal in which the tribunal found that the subject matter of a contract reflecting the state function on maintenance and improvement of the Suez Canal was not sufficient for a finding on attribution inasmuch that the actual conduct was not in the exercise of state powers - Jan de Nul N.V. and Dredging International N.V. v. Arab Republic of Egypt, ICSID Case No. ARB/04/13, Award dated 6 November 2008, para. 169-171.

Garanti Koza LLPv. Turkmenistan, ICSID Case No ARB/11/20. 
to a state as a party to a contract, which was not the case. ${ }^{95}$ According to the respondent, the claimant failed entirely to discharge its burden of proof in affirming the attribution. The tribunal took references to contractual provisions in the context of attribution rather seriously. It started by finding the mandate of the state-related contracting party, TAY, and then proceeded to contractual provisions expressly connecting that party with Turkmenistan, before finally concentrating on some discrete obligations under the contract reflecting state functions. Of particular interest is the following part of the tribunal's reasoning, which illustrates how the result of ascertaining the content of contractual provisions 'on the face', or hermeneutically, were relied upon to reconfirm the attribution:

The connection between the Contract and the Government of Turkmenistan appears on the face of the Contract. TAY is identified in the Contract as "Owner." "Owner" is in turn defined as "State Concern 'Turkmenavtoyollary' acting on behalf of Turkmenistan Government." The Contract also provides that it "is concluded on the basis of Decree of the President of Turkmenistan No. 9429," and that it comes into effect after its registration with the Turkmen Ministry of Economy and Development. These provisions of the Contract confirm that the acts of TAY in furtherance of the Contract were attributable to Turkmenistan. Road and bridge construction is in any event a core function of government. An entity empowered by a State to exercise elements of governmental authority is for that purpose acting as an organ of the State. ${ }^{96}$ [emphasis added]

Owing to the relative clarity of contractual terms, contract interpretation in Garanti Koza v. Turkmenistan became limited to their literal reading. Like assembling a mosaic, the tribunal carefully selected various elements, which together provided a complete picture on attribution: the mandate of a staterelated party, approval of a contract, the peculiarity of contractual obligations, etc.

95 For clarity, the respondent made a rather nuanced observation stressing that the claimant, while not directly affirming the respondent as being a party to a contract, nevertheless based its position on that assumption - Garanti Koza LLPv. Turkmenistan, ICSID Case No ARB/11/20, Award dated 19 December 2016, para. 281. 


\subsubsection{Expropriation}

Contracts naturally appear central for a decision on their expropriation. Under customary international law, it has long been recognised that contractual rights may become an object of expropriation. ${ }^{97}$ In international investment law, this understanding has become even more readily accepted because contracts receive a clear form of materialisation and are regularly recognised as being part of investments.

This does not mean that findings on contract expropriation have a low threshold. There is a strong view that only contracts marked by property features and capable of alienation or assignment could become an object of expropriation in the first place..$^{98}$ Furthermore, not any contractual breach amounts to expropriation, but those exercised as jure imperii and leading to substantial deprivation. ${ }^{99}$ Finally, other conditions for deciding on the unlawfulness of expropriation also have to be met. Overall, investment treaty arbitration does not alter the basic principle recognising that states have a right to expropriate and that expropriation becomes illegal only if conducted for reasons beyond those in

97 For a brief historical overview of cases on expropriation under international law in the period prior to investment treaty arbitration, see Christopher F Dugan, Investor-State Arbitration (Oxford University Press 2011) 430-438; for cases on expropriation of contractual rights in the practice of the Iran-USA Claims Tribunal, see George H Aldrich, The Jurisprudence of the Iran-United States Claims Tribunal (Clarendon Press 1996) 188196; Charles N Brower and Jason D Brueschke, The Iran-United States Claims Tribunal (Martinus Nijhoff Publishers 1998) 417-427, 634-635; Rosalyn Higgins, 'The Taking of Property by the State: Recent Developments in International Law' (1988) 176 Recueil des Cours de l'Académie de Droit International 271-273; 298-321. For more discussion on protection accorded to state contracts as property under customary international law, see Chapter 3 .

98 The distinction that only property rights based on a contract can be expropriated has found particular clarification in Emmis International Holding, B.V., Emmis Radio Operating, B.V., MEM Magyar Electronic Media Kereskedelmi és Szolgáltató Kft. v. The Republic of Hungary, ICSID Case No. ARB/12/2, Award dated 16 April 2014, para. 159169 and Accession Mezzanine Capital L.P. and Danubius Kereskedöház Vagyonkezelö Zrt. v. Hungary, ICSID Case No. ARB/12/3, Award dated 17 April 2015, para. 146-158; Waste Management v. Mexico, Award of 30 April 2004, para. 174-175. See also, Campbell McLachlan and others, International Investment Arbitration: Substantive Principles (2nd edn, Oxford University Press 2017) 408-409, Christopher F Dugan and others, InvestorState Arbitration (Oxford University Press 2011) 439-441.

99 Jean Ho, State Responsibility for Breaches of Investment Contracts (Cambridge University Press 2018) 162-171; Rudolf Dolzer and Christoph Schreuer, Principles of International Investment Law (2nd edn Oxford University Press 2012) 128-129. 
the public interest and in violation of due process without prompt, adequate and effective compensation. ${ }^{100}$

That a decision on expropriation is necessarily a fact-finding and contextdependent exercise ${ }^{101}$ does not exclude contract interpretation. Allegations of regulatory expropriation of contractual rights may require ascertaining the availability of any assurances for stabilisation, economic equilibrium in the contract or other undertakings pertaining to the economic rationale of a contract, their content and implication. ${ }^{102}$ Expropriatory cancellation of a contract may require a close look at the parties' mutual undertakings and the precise operation of a termination clause in the contract. ${ }^{103}$ Above all, the gravity of state interferences with various contractual rights, necessary for findings on expropriations of contractual rights, cannot be properly assessed without clarity of what the contract provides for in its entirety.

In somewhat more distinct forms, contract interpretation appears in relation to claims for expropriatory cancellation, where the question as to whether a state has terminated a contract contractually has to be answered. For instance, in Vigotop Limited $v$. Hungary, the tribunal had to establish whether a certain breach fell into those that justified termination under the concession contract. The tribunal observed:

The failure to establish the Concession Company within the same territory as the certified Project site does not qualify as a breach of Clause 9.3 in conjunction with Clause 7.1.2, but as a breach of Clause 7.1.2 only.

100 Only the wording of IIAs on certain conditions for legitimate expropriation may somewhat differ; see, for instance, Andrew Newcombe and Lluís Paradell, Law and Practice of Investment Treaties: Standards of Treatment (Kluwer Law International 2009) 377-385.

101 Because of the rejection of the claim of expropriation on factual/evidentiary grounds, the tribunal may not have a chance of contract interpretation. For instance, in İçkale İnşaat Limited Şirketiv. Turkmenistan, the tribunals denied a claim of expropriation emphasising a failure to prove that the contracts were terminated by a state or through state interference - see İçkale İnşaat Limited Şirketi v. Turkmenistan, ICSID Case No. ARB/10/24, Award dated 8 March 2016, para. 350-355.

102 AES Summit Generation Limited and AES-Tisza Erömü Kft. v. Republic of Hungary (II), ICSID Case No. ARB/07/22, Award dated 23 September 2010, para. 9.3.25; Azurix Corp. v. The Argentine Republic, ICSID Case No. ARB/O1/12, Award dated 14 July 2006, para. 314-322.

103 Vigotop Limited v. Hungary, ICSID Case No. ARB/11/22, Award dated 1 October 2014, para. 148, 193, 457, 473, 516-518; Malicorp Limited $v$. The Arab Republic of Egypt, ICsid Case No. ARB/o8/18, Award dated 7 February 2011, para. 126; Railroad Development Corporation v. Republic of Guatemala, ICSID Case No. ARB/o7/23, Award dated 29 June 2012, para. 141-142. 
However, such breach is not included within the grounds for termination listed in Clause 15.2.1, which has been invoked by Respondent in its Termination Letter. Thus, the Contract itself does not provide for termination on this basis. ${ }^{104}$

Overall, because of the focus on substantial deprivation of contractual rights, the interpretation exercised in the context of expropriation tends towards textualism. Tribunals do not as a rule engage in considering the implications of peculiar provisions but concentrate on the core of contractual arrangements.

\subsubsection{Fair and Equitable Treatment}

The necessity for contract interpretation may arise more often and at full intensity when treaty-based tribunals consider the FET violations. ${ }^{105}$ The standard is extremely prolific in terms of being one of the most frequently ${ }^{106}$ and most successfully ${ }^{107}$ invoked in investment arbitration. FET protects against arbitrary and non-transparent conduct, denial of justice and violation of due process, failure to provide a stable legal environment and various state conducts in bad faith. Its wide-ranging nature has led some authors to conclude that FET is 'the broadest

104 Vigotop Limited v. Hungary, ICSID Case No. ARB/11/22, Award dated 1 October 2014, para. 518 .

105 For an overview of FET, see Katia Yannaca-Small, 'Fair and Equitable Treatment Standard: Recent Development' in August Reinisch(ed), Standards of Investment Protection (Oxford University Press 2008) 111-130, Christoph Schreuer, 'Fair and Equitable Treatment in Arbitral Practice' (2005) 6(3) Journal of World Investment \& Trade 357; Rudolf Dolzer and Christoph Schreuer, Principles of International Investment Law (2nd edn, Oxford University Press 2012) 130-16o; UnCTAD, Fair and Equitable Treatment: A Sequel, UNCTAD Series on Issues in International Investment Agreements II (United Nations 2012) 17-35; Kenneth J Vandevelde, 'A Unified Theory of Fair and Equitable Treatment' (2010) 43(2) New York University Journal of International Law and Politics 43; Campbell McLachlan and others, International Investment Arbitration: Substantive Principles (2nd edn, Oxford University Press 2017) 296-336; Jean Ho, State Responsibility for Breaches of Investment Contracts (Cambridge University Press 2018) 101-138, 254-277.

106 According to the UNCTAD Investment Policy Hub, violation of FET was claimed in 460 cases - see <https://investmentpolicy.unctad.org/investment-dispute-settlement> accessed 30 January 2019; Christoph Schreuer names FET as 'the most promising standard of protection from the investor's perspective'. He further suggests that non-invocation of FET, if such a standard is available under applicable IIAs, may even be considered a form of 'malpractice' - see Christoph Schreuer, 'Introduction: Interrelationship of Standards' in August Reinisch (ed), Standards of Investment Protection (Oxford University Press 2008) 2.

107 According to UnCTAD Investment Policy Hub, violation of FET was found in 121 cases, which is the most frequently found violation of IIAs - see <https://investmentpolicy.unc tad.org/investment-dispute-settlement> accessed 30 January 2019. 
and most prominent standard in investment treaties, ${ }^{108}$ while for others the standards 'grant considerable discretion to tribunals to review the 'fairness' and 'equity' of government actions in light of all of the facts and circumstances of the case. ${ }^{109}$

At the same time, FET is not open to undue stretching. The debate is still ongoing in scholarly works and in the practice of investment treaty arbitration as to whether to keep attempting to understand FET in IIAS, within the minimum standard of protection under customary international law, or to permit a larger scope of protection independent from the minimum standard of protection. ${ }^{110}$ There is also an increasing understanding that despite the overlap, FET shall not be used merely as a loose substitute for expropriation that was discussed above, or as an umbrella clause to be addressed in the subsequent section. As a standard of investment protection, FET may protect the same values, but necessitates somewhat different requirements, which, depending on the context of a specific case, may be easier or more difficult to achieve. ${ }^{111}$ Furthermore, while certainly reflecting the general principle of good faith, ${ }^{112}$ the principle does not operate as a proxy for deciding a dispute ex aequo et bono.

Following a suggestion by Campbell McLachlan, Laurence Shore and Matthew Weiniger, it may be somewhat easier to understand FET through the three dimensions of the state function - judicial, legislative and executive. ${ }^{113}$ In the context of judicial function, the standard would respond to denials of justice, undue delays and serious deficiencies of due process. In the context of legislative function, the standard would respond primarily to violations of the legitimate expectations of regulatory stability. In the context of executive function, the standard would protect due process in administrative decisionmaking as well as its substantive fairness, proportionally and in response to legitimate expectations.

Unsurprisingly, contracts receive protection under FET against a broad variety of state interferences ranging from non-compliance with contractual

108 Rudolf Dolzer, 'Fair and Equitable Treatment: Today's Contours' (2014) 12(1) Santa Clara J.Int'l L. $7,10$.

109 Nigel Blackaby and others, Redfern and Hunter on International Arbitration (6th edn, Oxford University Press 2015) 476.

110 Rudolf Dolzer and Christoph Schreuer, Principles of International Investment Law (Oxford University Press 2012) 134-139.

111 Jean Ho, State Responsibility for Breaches of Investment Contracts (Cambridge University Press 2018) 255-270.

112 Rudolf Dolzer and Christoph Schreuer, Principles of International Investment Law (Oxford University Press 2012) 156-159.

113 Campbell McLachlan and others, International Investment Arbitration: Substantive Principles (2nd edn, Oxford University Press 2017) 296. 
undertakings of varying gravity to judicial interference and legislative changes undermining the regulatory stability of a contract or otherwise negatively affecting it. What precisely receives protection appears to be legitimate expectations of a foreign investor. According to some, the concept of legitimate expectations originates from domestic administrative law. ${ }^{114}$ For others, it has evolved from a simple interpretative tool to a self-standing concept dominating in $\mathrm{FET}^{115}$ and observable in other substantive standards of investment protection. ${ }^{116}$ Apart or in addition to contracts, legitimate expectations may be based on other sources of state assurances which may include informal representations and general legal frameworks.

Contracts appearing as a source of legitimate expectations do not cause much disagreement, in principle. ${ }^{117}$ More controversy appears when a discussion turns to concrete assessment. Not every contractual undertaking automatically reaches the level of protectable legitimate expectations and

114 Michele Potestà, 'Legitimate Expectations in Investment Treaty Law: Understanding the Roots and the Limits of a Controversial Concept' (2013) 28(1) ICSID Review 93-8, 121.

115 Thomas Wälde emphasised the evolution of legitimate expectations in the NAFTA context from 'a subsidiary interpretative principle to reinforce a particular interpretative approach chosen' to 'a self-standing subcategory and independent basis for a claim'; see Separate Opinion of Thomas Wälde in International Thunderbird Gaming Corporation v. The United Mexican States, para 37. For a critical observation that FET shall not be reduced to just one element of legitimate expectations, see Kenneth J Vandevelde, 'A Unified Theory of Fair and Equitable Treatment' 43(2) New York University Journal of International Law and Politics 43,67 .

116 For a view on the broader reach of legitimate expectations that is also inherent in other standards and provisions of international investment law like expropriation, umbrella clauses and compensation, see Ivar Alvik, Contracting with Sovereignty: State Contracts and International Arbitration (Hart 2011) 159-237. Some BITs contain express references to legitimate or reasonable expectations as part of another standard of investment protection, namely that of indirect expropriation. Examples include the Canada Model BIT 2004, the Norwegian Model BIT 2015 (draft) and the USA Model BIT 2012. The FET of these Model BITs does not have a textual reference to legitimate expectations. For a minority position which denies the place of legitimate expectations in the FET standard, see Judge Nikken's separate opinion in AWG Group $v$. Argentina, Separate Opinion of Arbitrator Pedro Nikken, para. $2-7$.

117 As Michele Potestà explains 'the contracts engender expectations which have to be placed at the highest level of protection - contracts usually reflect the carefully negotiated balance achieved by the opposing parties and could be said to crystallize the parties' expectations' - see Michele Potestà, 'Legitimate Expectations in Investment Treaty Law: Understanding the Roots and the Limits of a Controversial Concept' (2013) 28(1) ICsID Review 88, 103. Christoph Schreuer and Rudolf Dolzer also emphasise the relevance of contractual arrangements for the application of FET: '[c]ontractual agreements are the classical instrument in most, if not all, legal systems for the creation of legal stability and predictability' - see Rudolf Dolzer and Christoph Schreuer, Principles of International Investment Law (Oxford University Press 2012) 152. 
triggers FET in case of non-compliance. ${ }^{118}$ Divergent practices may be found in which tribunals considered an undertaking to pay under a contract as triggering legitimate expectations protectable under FET in one context, like in SGSv. Paraguay, ${ }^{119}$ or not, such as in Biwater Gauffv. Tanzania. ${ }^{120}$ Under these circumstances, any generalisation of criteria for qualifying or determining when contractual undertakings trigger legitimate expectations appears to be challenging. It would not be improper to suggest that treaty-based tribunals should take into account various factors, including the importance of an undertaking in question for the whole transaction, as well as a political and socio-economical context in the state, at the time of the contract's conclusion. ${ }^{121}$ Some scholars develop somewhat peculiar theoretical foundations for FET where, for instance, instead of legitimate expectations the core standard of treatment is identified as forming the basis for assessment of FET violation. ${ }^{122}$ Regardless of the ultimate decision as to whether a certain contractual undertaking ultimately triggers legitimate expectations of a foreign investor or not, ascertainment of its content becomes an indispensable part of the decision on FET. This is where contract interpretation appears on the scene.

To establish whether there has been a violation of FET, either in respect to the overall contract or in respect to individual clauses, a tribunal should look at the essence of the contractual arrangement and should interpret that arrangement, if necessary. Interpretation thus exercised is driven by a necessity to ascertain the expectations of a foreign investor that are protected by international investment law. Of the three cumulative elements of legitimate

118 Christoph Schreuer, 'Fair and Equitable Treatment in Arbitral Practice' (2005) 6(3) Journal of World Investment \& Trade 38 o.

119 SGS Société Générale de Surveillance S.A. v. The Republic of Paraguay, ICSID Case No. ARB/ 07/29 Decision on Jurisdiction of 12 February 2010, para. 146.

120 Biwater Gauff (Tanzania) Limited v. United Republic of Tanzania, ICsID Case No. ARB/O5/ 22, Award dated 24 July 2008, para. 636 .

121 See, for instance the clarification in Duke Energy Electroquil Partners and Electroquil S.A.v Ecuador: '[ $\mathrm{t}$ ] o be protected, the investor's expectations must be legitimate and reasonable at the time when the investor makes the investment. The assessment of the reasonableness or legitimacy must take into account all circumstances, including not only the facts surrounding the investment, but also the political, socioeconomic, cultural and historical conditions prevailing in the host State. In addition, such expectations must arise from the conditions that the State offered the investor and the latter must have relied upon them when deciding to invest' - see Duke Energy Electroquil Partners and Electroquil S.A. v. Ecuador, Award dated 18 August 2008, para. 340 .

122 Jean Ho, State Responsibility for Breaches of Investment Contracts (Cambridge University Press 2018) 90-138. 
expectations suggested by Ivar Alvik, ${ }^{123}$ two might pose relevant questions for contract interpretation. The first is whether there are specific expectations as regards contractual undertakings and the second is whether those undertakings are entered into and relied upon in relation to a specific investment. The first question would lead to a discussion of the binding and non-binding character of the undertakings and specify their content and scope. The second question would necessitate looking at the connection between the overall undertaking and the investment in question. Either expressly or implicitly, tribunals verify these legitimate contract-based expectations in light of these two questions.

Contract interpretation in the context of FET comes in all forms. While analysis may be viewed as emphasising the subjective intent, or expectations of one contractual party only (a foreign investor), this impression is wrong. Treaty-based tribunals tend to ascertain the content of contractual provisions which raise legitimate expectations objectively and reasonably. The approach may be compared with contract interpretation exercised in relation to a nonparty to a contract, i.e. based on the apparent meaning of the text and its reasonableness ${ }^{124}$ and with regard being given to the various potentially relevant circumstances. ${ }^{125}$ It is therefore not uncommon that textual analysis drives the tribunals' efforts when they often accept the absence of a textual expression of certain undertakings as a preclusion for further interpretative efforts and a confirmation of a lack of legitimate expectations. Contract interpretation may also become somewhat deeper and more contextual in situations in which the contract does not textually reflect the full scope of reasonable expectations that a foreign investor may have on its basis. On these occasions, tribunals may take the purpose of the transaction into account, as well as other contractual provisions and the relevant contexts surrounding the transaction, to infer certain undertakings as a basis for legitimate expectations.

There is a broad consensus that FET as a standard of investment protection is not supposed to address separate or discrete violations of contractual

123 Ivar Alvik explains that the concept of legitimate expectations has three 'basic and cumulative elements' consisting of (1) specific expectations pursuant to contractual or comparably definite undertakings of a state, which (2) have been entered into and relied on in relation to specific investments, and which (3) have subsequently been repudiated by the state in its government or political capacity. See Ivar Alvik, Contracting with Sovereignty: State Contracts and International Arbitration (Hart 2011) 160.

124 See for instance, an articulated approach towards contract interpretation if a question arises in relation to a third party relying on a contract term in Article II.-8:101 (3) (b) Draft Common Frame of Reference.

125 Article II.-8:102 (2) of the Draft Common Frame of Reference. 
provisions, but rather a substantial intervention in the overall integrity of a contract. Stabilisation, renegotiations and economic equilibrium clauses, together with provisions on price adjustment, payment and contract termination are the frequent candidates for interpretative efforts in the context of FET. These provisions, although distinct, ultimately shape the overall integrity of an investment transaction: the stability of the legal framework surrounding contractual provisions (stabilisation clause, renegotiations, economic equilibrium clauses, predictability of the regulation on termination), the financial essence or foundation of a bargain (payment clause) and a predictable framework of contractual relations (termination clause). The examples below illustrate the point.

In Parkerings $v$. Lithuania ${ }^{126}$ for instance, the tribunal expressly tied a lack of legitimate expectations to the failure to incorporate a stabilisation clause into the contract:

By deciding to invest notwithstanding this possible instability, the Claimant took the business risk to be faced with changes of laws possibly or even likely to be detrimental to its investments. The Claimant could (and with hindsight should) have sought to protect its legitimate expectations by introducing into the investment agreement a stabilization clause or some other provisions protecting it against unexpected and unwelcome changes. ${ }^{127}$

Similarly, a treaty-based tribunal found ambiguous rights on exclusivity in a contract on the operation of duty free stores in Moldova as being not sufficient for implying contractual undertakings of exclusivity and on their basis legitimate expectations of a foreign investor in Mr. Franck Charles Arif v. Republic of Moldova:

552. This 'exclusive right' was defined in Clause 1.1.: "Exclusive rights: exclusive right of the Investor to manage and administrate the duty-free store network at the state border crossing points is established by the Government Decision no. 172 of 18 February 2008 at the exclusive managerial risk of the Investor according to the provisions of this Agreement. The exclusive rights of the Investor shall not be opposable any longer to the Authority when, following the organization, according to the legislation, of a public

126 Parkerings-Compagniet AS v. Republic of Lithuania, ICsID Case No. ARB/ o5/8.

127 Ibid. Award dated 11 September 2007, para. 336. 
tender, a third party shall obtain the right to build and open dutyfree-stores at the state border crossing points."

553. This is a qualified and ambiguous exclusive right. It refers to the Tender ("Government Decision no. 172 of 18 February 2008") but this Tender, as already mentioned, did not offer or establish any exclusive right. Further, the definition in fact recognised that the Authority could conduct another tender to allow a third party to build and open duty free stores, so the 'exclusivity' was not expected to endure any longer than the Authority required to organise such a tender.

554. The qualified and ambiguous references to exclusivity do not support a legitimate expectation that Claimant would have an exclusive right to operate duty free stores at the border locations. The only legitimate expectation of Claimant for the purposes of the fair and equitable treatment obligation in Article 3 of the BIT in relation to the border stores was the more generalised expectation that Claimant was entitled to open duty free stores at five named border locations, and that the State would co-operate with him in this regard. ${ }^{128}$ [emphasis added]

Approaching a contract somewhat differently in $M T D v$. Chile, the treaty-based tribunal deemed there to be legitimate expectations even in the absence of an express undertaking. ${ }^{129}$ The contract related to a residential development project and an undertaking at stake concerned a zoning modification of the land necessary for the realisation of the project. The claimant in particular asserted that:

[the respondent] created and encouraged strong expectations that the Project, which was the object of the investment, could be built in the specific proposed location and entered into a contract confirming that location, but then disapproved that location as a matter of policy after MTD irrevocably committed its investment to build the Project in that location. ${ }^{130}$

128 Mr. Franck Charles Arif v. Republic of Moldova, ICSID Case No. ARB $/ 11 / 23$, Award dated 8 April 2013, para. $55^{2-554}$ (it should be noted that the decision on lack of legitimate expectations was premised on broader considerations beyond conclusions relating to the clause on exclusivity).

129 MTD Equity Sdn. Bhd. and MTD Chile S.A. v. Republic of Chile ICSID Case No ARB/o1/7.

130 Ibid. Award dated 25 May 2004, para. 116. 
The claimant suggested that the contract had to be interpreted 'with its plain language and the general principles of contract law, in keeping with the internationalization of contract obligations.131 The claimant further substantiated their own legitimate expectations by referencing the fact that the contract was one of adhesion, in which the investor accepted the terms offered. At the same time, the claimant specified that both parties shared a common understanding that the necessary permits, including zoning modification, were mere formalities. ${ }^{132}$ Having assessed the contractual undertakings in relation to the realisation of the residential development project in their totality, the tribunal found that a foreign investor could validly assume legitimate expectations that a necessary permit for the project zoning modification would be granted. The tribunal extended legitimate expectations beyond express contractual provisions on the basis of what would be a reasonable assumption from the terms the parties actually agreed:

As already discussed under fair and equitable treatment, what is unacceptable for the Tribunal is that an investment would be approved for a particular location specified in the application and the subsequent contract when the objective of the investment is against the policy of the Government. Even accepting the limited significance of the Foreign Investment Contracts for purposes of other permits and approvals that may be required, they should be at least in themselves an indication that, from the Government's point of view, the Project is not against Government policy. ${ }^{133}$ [emphasis added]

Similarly, the tribunal implied certain legitimate expectations from the preamble and various other contractual provisions of the privatisation contract in Eureko B.V. v. Poland ${ }^{134}$ (the case is addressed in more detail in the conclusive chapter of this work from a position of failure to apply national law to contract interpretation, which MTD v. Chile can also be criticised for).

Overall, one can come across diverse approaches to contract interpretation. Textualism, while noticeable, does not belong to a dominant interpretative preference exercised in the context of FET. Depending on the circumstances

\footnotetext{
131 Ibid. para. 179.

132 Ibid. para. 180.

133 Ibid. para. 189 .

134 Eureko B.V. v. Republic of Poland, Ad Hoc Arbitration under the Agreement between the Kingdom of the Netherlands and the Republic of Poland on Encouragement and Reciprocal Protection of Investment, Partial Award of 19 August 2005, para. 53, 136, 152.
} 
of a particular case, tribunals may find it rewarding to look at contractual purpose and other relevant considerations and to imply some contractual undertakings on their basis.

\subsubsection{National Treatment and Most-Favoured-Nation Treatment}

It may not be immediately apparent whether contract interpretation may take place in the context of national treatment and MFN. ${ }^{135}$ While indeed rare, the standards should not be discarded altogether as having nothing to do with ascertainment of the content of contractual provisions. Both national treatment and MFN are contingent standards of investment protection. ${ }^{136}$ They depend on a careful comparison of the treatment afforded to a foreign investor: in the case of national treatment - with/to national or local investors in the same business sector, and in the case of $\mathrm{MFN}$ - with/to treatment accorded to other foreign investors. National treatment presupposes a relatively simple comparative exercise focused on the most detectable differences in the treatment of a foreign investor and of a national investor assessed reasonably. Analysis of MFN concentrates as a rule on the comparison of standards of investment protection and (with much debate) procedural regulation. The example below illustrates a case which could have been a good case for contract interpretation hadn't the parties settled.

In Noble Energy, Inc. and Machalapower Cia. Ltda. v. The Republic of Ecuador and Consejo Nacional de Electricidad, ${ }^{137}$ the claimants argued that Ecuador breached various treaty obligations and contractual obligations, including an obligation not to discriminate. One of the claimants had entered into a

135 It is not rare that the application of the standard ends at factual observations confirming the absence of similar circumstances for a meaningful comparison. In Mobil Exploration and Development Inc. Suc. Argentina and Mobil Argentina S.A. v. Argentine Republic, the claimant alleged discrimination and arbitrary treatment in comparison with producers who signed specific contracts with the state (signatory producers). The tribunal refused to find a violation of arbitrary and discriminatory conduct without digging into the content of contracts but rather performed an assessment on general terms and concluded that signatory and non-signatory producers were not in the same circumstances - Mobil Exploration and Development Inc. Suc. Argentina and Mobil Argentina S.A. v. Argentine Republic, ICsid Case No. arb/04/16, Decision on Jurisdiction and Liability, 10 April 2013, para. $891-893$.

136 Campbell McLachlan and others, International Investment Arbitration: Substantive Principles (2nd edn Oxford University Press 2017) 336-353; Andrea Bjorklund, 'National Treatment' in August Reinisch (ed), Standards of Investment Protection (Oxford University Press 2008) 29-58.

137 Noble Energy, Inc. and Machalapower Cia. Ltda. v. The Republic of Ecuador and Consejo Nacional de Electricidad, ICSID Case No. ARB/05/12. 
concession agreement with Ecuador for the construction, installation and operation of an electric power generation plant with authorisation to generate electricity and sell it to the wholesale electricity market in the country. Another claimant concluded an investment agreement with Ecuador in relation to the concession contract under which the claimant planned to invest USD228,200,000 to be made during the term of the Concession Contract, whereas Ecuador provided certain guarantees in relation to investments. An allegation of discrimination was submitted under various premises and in relation to various sets of facts. The claimants argued, in particular, that Ecuador breached national treatment and $\mathrm{MFN}$ by providing more preferential terms to Colombian power generators. Furthermore, the claimant relied upon contractual terms on non-discrimination, or a term of the most favoured concessionaire, in the concession contract concluded with the state, which was supposed to ensure that the claimants received no less favourable treatment than 'other electric power generation concessionaires, whether individuals or corporations'.138 Interpreting the provision, the claimants even submitted that the more favourable regime with other power producers therefore should be deemed to be incorporated 'pari passu' into their contract. ${ }^{139}$ Had the case not been settled at the merits stage with USD70 million being paid to the claimants, it would have been interesting to see the precise interpretation of contractual terms on non-discrimination in its interplay with the treaty standards on national treatment and most-favoured-nation treatment in the EcuadorUnited States of America BIT (1993) in force at the time of the investment and applicable in this case. Given that both standards are premised on comparison, it is rather likely that approaches to contract interpretation would not step beyond textualism.

\subsubsection{The Umbrella Clause}

Treaty-based tribunals have to ascertain the content of contractual provisions when deciding on the application of a specific standard of investment protection - the umbrella clause. ${ }^{140}$ Umbrella clauses appeared in the first drafts

${ }_{13} 8$ Ibid. Decision on Jurisdiction dated 5 March 2008, para. 173.

139 Ibid. 174.

140 While the umbrella clause is nowadays a commonly recognisable term, the provision may also be found as being referred to as a 'mirror effect', 'elevator', 'parallel effect', 'sanctity of contract', 'respect clause' and merely 'pacta sunt servanda', 'observance of specific investment undertakings' or 'observance of undertakings clause' - see Katia Yannaca-Small, 'Interpretation of the Umbrella Clause in Investment Agreements' (2006) OECD Working Papers on International Investment No 2006/o3, 1 < https://www.oecd.org/investment/ internationalinvestmentagreements/WP-20o6_3.pdf > accessed 26 September 2021; 
of the multiparty treaties on the protection of foreign investments in the late 195 os to early 196 os as a reflection of the principle of pacta sunt servanda ${ }^{141}$ and since that time have spread across numerous IIAs with various wordings. ${ }^{142}$ This treaty provision aims to ensure the observation of specific obligations, which a state undertakes in respect to a foreign investor, including contractbased undertakings. ${ }^{143}$ The frequency of contract interpretation exercised in the framework of umbrella clauses is comparable to interpretation exercised under FET with some allowance for a number of IIAs containing umbrella clauses in comparison to a number of IIAs with FET. The lesser number of IIAs with umbrella clauses in comparison to IIAs with FET makes reliance on umbrella clauses somewhat less frequent than reliance on FET. Furthermore, when the same factual circumstances and contractual provisions trigger both FET and the umbrella clauses, tribunals may either interpret provisions in the framework of one standard only and thereafter rely on that interpretation when assessing a claim under an umbrella clause or treat a decision on an umbrella clause as a more controversial standard to be moot. ${ }^{144}$

Many controversies surround the provision. The most critical disagreements relate to the possibility that the umbrella clause could transform a pure contractual breach into a treaty breach. It remains unclear whether any contract breach shall be automatically equated to a treaty breach and how far the umbrella clause departs from a position on contract protection under customary international law. Some disagreement also touches on the question of the internationalising effect of the umbrella clause and its impact on the national law applicable to a contract. A further area of uncertainty relates to some disagreements as to whether a state should be a contracting party directly and

Nigel Blackaby and others, Redfern and Hunter on International Arbitration (6th edn, Oxford University Press 2015) 488; Rudolf Dolzer and Christoph Schreuer, Principles of International Investment Law (2nd edn, Oxford University Press 2012) 166.

141 Anthony C Sinclair, 'Origins of the Umbrella Clause in the International Law of Investment Protection' (2004) 20(4) Arbitration International 411.

142 The most repeated figure in relation to the umbrella clause is its presence in $40 \%$ of the existing IIAs quoted in the Katia Yannaca-Small, 'Interpretation of the Umbrella Clause in Investment Agreements' (2006) OECD Working Papers on International Investment No 2006/o3, 1 < https://www.oecd.org/investment/internationalinvestmentagreements/ WP-2006_3.pdf> accessed 26 September 2021.

143 The umbrella clause is also discussed in the context of unilateral state promises - see María Cristina Gritón, 'Do Umbrella Clauses Apply to Unilateral Undertakings?' in Christina Binder and others (eds), International Investment Law for the 21st Century: Essays in Honour of Christoph Schreuer (Oxford University Press 20o9) 490-96.

144 Murphy Exploration \& Production Company-International v. The Republic of Ecuador II, Final Award dated 10 February 2017, para. 29-32. 
what the appropriate rules for deciding who the contracting parties to a contract are. Finally, continuing controversy exists as to whether a forum selection clause in a contract constitutes a jurisdiction impediment to a claim on the basis of an umbrella clause.

One may see certain correlations between uncertainty in the application of umbrella clauses and their spread in IIAs. In the jurisprudence of investment treaty arbitration, the controversies surrounding umbrella clauses came to light first in 2003-2004 when on the face of apparently similar wordings treaty-based tribunals disagreed on its effect. ${ }^{145}$ Save for an identifiable agreement that an umbrella clause does not change the law applicable to a contract, so far not much consensus has been reached in relation to other areas of uncertainty. The absence of conclusive answers to these questions made the umbrella clause less attractive for states. Despite a relatively low success rate of reliance on the provision, ${ }^{146}$ a trend of excluding umbrella clauses from the new generation of FTAs and new Model BITs appears to be gaining momentum. ${ }^{147}$

That umbrella clauses are becoming less spread in IIAs, does not make them disappear. The provision remains enforceable through numerous IIAs. When tribunals give full effect to it, they may also need to ascertain the content of

145 The two decisions in which umbrella clauses demonstrated different effects are SGS v. Pakistan, Decision on Jurisdiction dated 6 August 2003 and SGS v. Philippines, Decision on Jurisdiction dated 29January 2004. For a summary of key disagreements about umbrella clauses, with a broader overview of available jurisprudence, see Campbell McLachlan and others, International Investment Arbitration: Substantive Principles (2nd edn, Oxford University Press 2017) 128 -140; Jean Ho, State Responsibility for Breaches of Investment Contracts (Cambridge University Press 2018) 196-214; Rudolf Dolzer and Christoph Schreuer, Principles of International Investment Law (2nd edn, Oxford University Press 2012) 166-178; Nigel Blackaby and others, Redfern and Hunter on International Arbitration (6th edn, Oxford University Press 2015) 488-49o.

146 According to the UNCTAD Investment Policy Hub, the provision has been relied upon in 125 cases and its breach was found only in 17 cases, i.e. 13.6\% - see UNCTAD Investment Policy Hub <https://investmentpolicy.unctad.org/investment-dispute-settlement> accessed 30 January 2019. Unsuccessful cases are not necessarily a sign of a dominant restrictive approach towards the interpretation of umbrella clauses diminishing its independent operation. A denial of a claim based on an umbrella clause may be explained by a failure to prove factual components.

147 My calculations show that the umbrella clause was increasingly used in the first five decades from its appearance, reaching $5^{2.11} \%$ of the concluded IIAs, whereas the last 16 years (calculated up to 2017 ) witnessed an abrupt decline from $52.11 \%$ to $22.98 \%$, i.e. by $29.13 \%$. The initial draft of the research paper was presented at the conference of the Max Planck Institute Luxembourg for International, European and Regulatory Procedural Law on 24-25 November 2016 'DEBACLES - Illusions and Failures in the History of International Adjudication' < https://www.mpi.lu/news-and-events/debacles-illusions-and-failures-inthe-history-of-international-adjudication/> accessed 25 June 2021. 
contractual undertakings underlying an international obligation of the state to perform its undertakings. By way of example, they may need to look at obligations to pay, ${ }^{148}$ to supply goods, ${ }^{149}$ to stabilise an entire contract, ${ }^{150}$ and others. One can hardly think of any other standard of investment protection coming so close to contractual undertakings in their pure form as the umbrella clause.

The reliance on plain text is reflected in many ways in awards. The selection of examples below illustrates loyalty to contractual texts:

- '[t]he Tribunal notes that Article 12 of the Concession Agreement makes explicit mention of shareholders' and further '[1] ogic as well as specific Concession language run counter to any suggestion that Claimant's rights to calculate tariffs in U.S. dollars were to depend on survival of the Convertibility Law' and finally '[s] uch finding is further supported by the text of the Currency Clause'; $; 51$

- ' $[\mathrm{t}] \mathrm{he}$ Tribunal must also note that Clause 18.2 of the License, in prohibiting the modification of the License makes special reference to the fact that ... the Licensee will have the right to request the pertinent adjustment of the tariff'; 152

- 'the Altai Agreement contains no express commitment not to amend ... and the Arbitral Tribunal finds no ground for implying any such commitment'; 153

148 SGS Société Générale de Surveillance S.A.v. Republic of Paraguay, ICSID Case No.AR B / o7/29, Award dated 10 February 2012, para. 79-156; SGS Société Générale de Surveillance S.A. v. Republic of the Philippines, ICSID Case No. ARB / o2/6, Decision on Jurisdiction dated 29January 2004, para.127-128; Garanti Koza LLPv. Turkmenistan, ICSID Case No. ARB/11/2O Award dated 19 December 2016, par. 328-359; Duke Energy Electroquil Partners and Electroquil S.A. v. Republic of Ecuador, ICSID Case No.ARB/o4/19, Award dated 18 August 2008, para. 317-325.

149 An alleged undertaking to supply blood plasma in David Minnotte and Robert Lewis v. Republic of Poland, ICSID Case No. ARB (AF)/10/1, Award dated 16 May 2014, para. 203 (the claim denied at the merits stage).

150 Enron Creditors Recovery Corporation (formerly Enron Corporation) and Ponderosa Assets, L.P. v. Argentine Republic, ICSID Case No. ARB/o1/3, Award dated 22 May 2007, para. 269277 (the tribunal construed the state undertakings on the basis of contracts, together with undertakings given through law and regulations).

$15^{1}$ EDF International S.A., SAUR International S.A. and Leon Participaciones Argentinas S.A. v. Argentine Republic, ICsID Case No. ARB/ 03/23, Award dated 11 June 2012, para. 942, 961, 965 .

152 Enron Creditors Recovery Corporation (formerly Enron Corporation) and Ponderosa Assets, L.P. v. Argentine Republic, ICSID Case No. ARB/o1/3, Award dated 22 May 2007, para. 155, see also para. 269-277.

153 AES Corporation and Tau Power B.V. v. Republic of Kazakhstan, ICsid Case No. ARB/10/16, Award dated 1 November 2013, para. 336 . 
- 'the Claimants have failed to refer to any provision of the Privatization Agreement which guarantees ... [i]ndeed, the Privatization Agreement does not contain any such assurance or guarantee. ${ }^{154}$ [emphasis added]

At the same time, tribunals may not always be satisfied by textual reading of the provisions only. It may be necessary for them to look at a larger scope of relevant circumstances in order to establish the precise content of the provisions. Tribunals may need, for instance, to look at pre-contractual material containing a provision which was ultimately excluded from the final text. They may also find it important to verify that interpretation does not deprive an agreement of practical effect. David Minnotte and Robert Lewis v. Republic of Poland illustrates a certain restrictive interpretation of the contractual text:

177. In the view of the Tribunal, the express terms of Article 4.1 cannot be construed as requiring the Respondent to deliver plasma for the purposes of pre-production testing, either on demand or by any given date. The Tribunal notes that a contractual term that would have imposed such a duty was included in a draft of the 1997 Fractionation Agreement but was not included in the agreed final text of the 1997 Fractionation Agreement.

178. The Respondent had monopoly control over the supply of Polish plasma (but not over all plasma; and non-Polish plasma could be and was used for the initial stage of the testing). It is certainly arguable that the Respondent was obliged to supply Polish plasma at some stage for testing purposes. That conclusion is at least arguably necessary in order to give the 1997 Fractionation Agreement practical effect: at some stage LFO had to obtain Polish plasma for testing from somewhere. But the Claimants' case requires more than that. ${ }^{155}$

Overall, textualism appears as a dominant perspective again, primarily because tribunals mostly focus on the objective of establishment of the existence of a legal obligation.

154 Vincent J. Ryan, Schooner Capital LLC, and Atlantic Investment Partners LLC v. Republic of Poland, ICsid Case No. ARB(AF)/11/3, Award dated 24 November 2015, para. 257.

155 David Minnotte and Robert Lewis v. Republic of Poland, ICSID Case No. ARB (AF)/10/1, Award dated 16 May 2014, para. 177-178. 


\subsubsection{Compensation}

When deciding on compensation for violations of standards of investment protection, treaty-based tribunals routinely engage in a complex analysis with different valuation factors. ${ }^{156}$ IIAs, as a rule, bring little clarity on the precise methodology to be used. ${ }^{157}$ Contracts appear in various perspectives in this context. Treaty-based tribunals may need to decide on compensation to be awarded for the expropriation of contractual rights, for the FET violation, or for other violations in relation to contractual rights. ${ }^{158}$ An economic value of contractual rights assessed in light of the internal contractual mechanism envisaging distribution of profits may become important for the assessment. ${ }^{159}$ Treaty-based tribunals may also need to evaluate the economic effect of contracts which do not trigger protection in investment treaty arbitration, such as a transaction between a claimant and a third party. ${ }^{160}$

Karkey Karadeniz Elektrik Uretim A.S. v. Islamic Republic of Pakistan ${ }^{161}$ illustrates a situation where a contractual provision in the investment contract appeared central for estimating an amount of compensation. The case arose out of the detention by Pakistan of electricity-generating vessels owned by the claimant, and breaches of contractual payment obligations for electricity

${ }_{15} 6$ Campbell McLachlan and others, International Investment Law: Substantive Principles (2nd edn, Oxford University Press 2017) 417-447; Thomas Wäelde and Borzu Sabahi, 'Compensation, Damages and Valuation' in Peter Muchlinsky and others (eds), The Oxford Handbook of International Investment Law (Oxford University Press 2008) 10491125; Christopher F Dugan and others, Investor-State Arbitration (Oxford University Press 2011) $573-583$.

157 IIAs may rather exceptionally provide for national law to be applicable for calculating compensation. For instance, Cyprus - Hungary вIт (1989) provides in Article 4(3) that: 'The amount of this compensation may be estimated according to the laws and regulations of the country where the expropriation is made', which was discussed in ADC Affiliate Limited and ADC \& ADMC Management Limited v. Republic of Hungary, ICSID Case No. ARB/o3/16, Award dated 2 October 2006, para. 292.

158 Ron Fuchs v. The Republic of Georgia, ICSID Case No. ARB/o7/15, Award dated 3 March 2010, para. 479-485; Ioannis Kardassopoulos v. The Republic of Georgia, ICsid Case No. ARB/05/18, Award dated 3 March 2010, para. 479-485; ConocoPhillips Petrozuata B.V., ConocoPhillips Hamaca B.V. and ConocoPhillips Gulf of Paria B.V. v. Bolivarian Republic of Venezuela, ICSID Case No. ARB/o7/30, Award of the Tribunal dated 8 March 2019, para. 92-93, 160-195, 207-229; Quiborax S.A., Non-Metallic Minerals S.A.v. Plurinational State of Bolivia, ICSID Case No. ARB/o6/2, Award dated 16 September 2015, para. 343-347.

159 Waguih Elie George Siag and Clorinda Vecchiv. The Arab Republic of Egypt, ICsid Case No. ARB / 05/15, Award dated 1 June 2009, para. 577-584.

160 CME Czech Republic B.V.v. The Czech Republic, Award dated 14 March 2003, para. 514, 560.

161 Karkey Karadeniz Elektrik Uretim A.S. v. Islamic Republic of Pakistan, ICSID Case No. ARB/ 13/1, Award dated 22 August 2017. 
generated by the claimant. Having found that contractual rights were expropriated, the tribunal proceeded to the calculation of compensation. Despite the objections of the respondent, the tribunal found contractual termination charges relevant and valid for determining compensation. ${ }^{162}$ In the tribunal's view, had the court not declared the contract void, the claimant could have terminated the contract and been entitled to receive termination charges as a sovereign guarantee. Regarding allegations of the respondent that the provision was a penalty prohibited under the law applicable to a contract, the tribunal applied a standard that reflected the well-known discussion on penalty clauses versus liquidated damages under English contract law. ${ }^{163}$ The tribunal concluded that the termination charges represented 'a precise and rational method for the calculation of a genuine pre-estimate of the loss in the case of termination of the Contract. ${ }^{164}$ Furthermore, while not framing its inquiry in terms of contra proferentem, the tribunal considered that the fact that the state drafted the disputed provision, and that the provision as such was inserted into a contract without further negotiations, was another relevant factor for a finding of its reasonableness. ${ }^{165}$ The tribunal accordingly observed that the provision on termination charges could not be perceived as an 'improper penalty'166 and was compliant with Pakistani law. The ultimate assessment of compensation due for the expropriation of contractual rights included, accordingly, the termination charges which the tribunal estimated to amount to USD149,802,431.

While Karkey Karadeniz Elektrik Uretim A.S. v. Islamic Republic of Pakistan demonstrates reliance on contractual provisions for calculating compensation, contractual provisions may also be used to limit or exclude compensation. ${ }^{167}$ The contractual limitation on compensation is not entirely settled in investment treaty arbitration. More discussion follows in Chapter 4 of this

162 Ibid. para. 686.

163 Ibid. para. 694. For a discussion on penalty clauses versus liquidated damages in ordinary commercial context, see Cavendish Square Holding BVv. Talal El Makdessi; Parking Eye Limited v. Beavis [2015] uksC 67; John Sharples, 'Supreme Court Changes Law Relating to Liquidated Damages and Penalty Clauses' (2015) <https://www.stjohnschambers.co.uk/ wp-content/uploads/2018/o8/Supreme-Court-changes-law-relating-to-liquidated-dama ges-and-penalty-clauses.pdf> accessed 25 June 2021; Richard Manly and Matthew Bell, 'Liquidated Damages and the Doctrine of Penalties: Rethinking the War on Terrorem' (2012) 29 The International Construction Law Review 386.

164 Karkey Karadeniz Elektrik Uretim A.S. v. Islamic Republic of Pakistan (ICsID Case No. ARB/ 13/1) Award dated 22 August 2017, para. 695.

165 Ibid. para. 697 .

166 Ibid. para. 698.

167 See, for instance, Toto Costruzioni Generali S.p.A. v. Republic of Lebanon (ICsid Case No. ARB / $07 / 12$ ), Award dated 7 June 2012, para. 85 . 
book where a doctrinal effect of contractual provisions, including contractual provisions on limitation on liability, are addressed.

Overall, one may distinguish textualism as a dominant interpretative preference. However, interpretation of the content of contractual provisions in the context of compensation is not necessarily limited to it. Tribunals may need to have a broader focus beyond the text to understand the precise content and intended operation of the provision in question.

\subsection{Procedural Setting}

The procedural setting under which tribunals interpret contracts in the analysed cases is rather diverse and essentially reflects 'the whole world' of investment treaty arbitration. The ICSID Arbitration Rules define the procedure in the majority of the analysed cases with elements of contract interpretation - 91 $(71 \%)$ out of all 128 cases (for the full list of 128 cases, see Annex IV). ${ }^{168}$ Cases conducted under the ICsID Arbitration Rules are cited most often in this work. The second place in terms of frequency belongs to the UnCITRAL Arbitration Rules - used in $20(16 \%)$ out of 128 cases. Of the three editions of the UNCITRAL Arbitration Rules, ${ }^{169}$ it is the earlies edition of 1976 that has been applied in most cases. The edition of 2010 has found application only in Khan Resources Inc., Khan Resources B.V., and Cauc Holding Company Ltd. v. The Government of Mongolia. A relatively insignificant number of cases conducted under the UNCITRAL Arbitration Rules received no administrative assistance by arbitral institution, ${ }^{170}$ whereas most were conducted with some administrative support provided by the PCA, ${ }^{171}$ the

168 For instance, Duke Energy Electroquil Partners \& Electroquil S.A. v. Republic of Ecuador, ICSID Case No. ARB/04/19; EDF International S.A., SAUR International S.A. and León Participaciones Argentinas S.A. v. Argentine Republic, ICsid Case No. ARB/o3/23; Enron Corporation and Ponderosa Assets, L.P. v. Argentine Republic, ICSID Case No. ARB/o1/3; Fraport AG Frankfurt Airport Services Worldwide v. Republic of the Philippines, ICsID Case No. ARB/11/12; Gustav F W Hamester GmbH \& Co KG v. Republic of Ghana, ICSID Case No. $\mathrm{ARB} / \mathrm{O} / 24$.

169 The UnCitral Arbitration Rules 1976, the UnCitral Arbitration Rules 2010 (revised) and the UnCitral Arbitration Rules 2013 (incorporating the Rules on Transparency for arbitration initiated pursuant to an investment treaty concluded on or after 1 April 2014).

170 Energoalians TOV v. Republic of Moldova; Oxus Gold v. Republic of Uzbekistan; Ronald S. Lauder v. The Czech Republic; Sergei Paushok, CJSC Golden East Company and CJSC Vostokneftegaz Companyv. The Government of Mongolia; Eureko B.V.v. Republic of Poland.

171 Chevron Corporation (USA) and Texaco Petroleum Company (USA) v. The Republic of Ecuador (PCA Case No. 34877); Chevron Corporation and Texaco Petroleum Corporation 
ICSID ${ }^{172}$ or the LCIA. ${ }^{173}$ The third place in terms of frequency was use of the ICSID Additional Facility Rules (12 cases or 9\%). ${ }^{174}$ The fourth place was use of the scc Arbitration Rules (4 cases or $3 \%$ ). ${ }^{175}$ There were also two cases conducted under the Arbitration Rules of the Moscow Chamber of Commerce and Industry (MCCI Arbitration Rules). ${ }^{176}$ While in the analysed cases with elements of contract interpretation, no other arbitration rules were used, it may appear that non-available cases which were excluded from the analysis or new cases with elements of contract interpretation are conducted under other arbitration rules, for instance the ICc Arbitration Rules, the LCIA Arbitration Rules, etc.

v. The Republic of Ecuador (PCA Case No. 2009-23); Flemingo DutyFree Shop Private Limited v. the Republic of Poland; Khan Resources Inc., Khan Resources B.V., and Cauc Holding Company Ltd. v. The Government of Mongolia (PCA Case No. 2011-o9); Luigiterzo Bosca v. Lithuania (PCA Case No. 2011-05); ST-AD GmbH v. Republic of Bulgaria (PCA Case No. 2011-o6); Ulysseas, Inc. v. The Republic of Ecuador (PCA Case No. 2009-19); Murphy Exploration \& Production Company International v. Republic of Ecuador, PCA Case No. 2012-16 (formerly AA 434); Saluka Investments B.V. v. The Czech Republic; Peter Franz Vocklinghaus v. Czech Republic.

172 For instance, AWG Group Ltd. v. The Argentine Republic.

173 Occidental Exploration and Production Company v. The Republic of Ecuador (LCIA Case No. UN3467); Werner Schneider, acting in his capacity as insolvency administrator of Walter Bau Ag (In Liquidation) v. Kingdom of Thailand.

174 The ICSID Additional Facility Rules apply when the ICSID Convention is not applicable. Anglo American PLC v. Bolivarian Republic of Venezuela, ICSID Case No. ARB(AF)/14/1; Crystallex International Corporation v. Bolivarian Republic of Venezuela, ICsid Case No. $\operatorname{ARB}(\mathrm{AF}) / 11 / 2$; David Minnotte \& Robert Lewis v. Republic of Poland, ICsID Case No. ARB (AF)/10/1; Gemplus S.A., SLP S.A., Gemplus Industrial S.A. de C.V. v. The United Mexican States, ICSID Case No. ARB (AF)/o4/3; Lao Holdings N.V.v. Lao People's Democratic Republic, ICSID Case No. ARB (AF)/12/6; Mercer International Inc. v. Government of Canada, ICSID Case No. ARB(AF)/12/3; MNSS B.V. and Recupero Credito Acciaio N.V.v. Montenegro, ICSID Case No. ARB $(\mathrm{AF}) / 12 / 8 ;$ Nova Scotia Power Incorporated v. Bolivarian Republic of Venezuela, ICSID Case No. $\operatorname{ArB}(\mathrm{AF}) / 11 / 1 ;$ Talsud S.A. v. The United Mexican States, ICsid Case No. $\operatorname{ARB}(\mathrm{AF}) / 04 / 4$; Vannessa Ventures Ltd. v. Bolivarian Republic of Venezuela, ICSID Case No. $\mathrm{ARB}(\mathrm{AF}) 04 / 6$; Vincent J. Ryan, Schooner Capital LLC, and Atlantic Investment Partners LLC v. Republic of Poland, ICSID Case No. ARB $(\mathrm{AF}) / 11 / 3$; Waste Management, Inc. v. United Mexican States ("Number 2"), ICSID Case No. ARB(AF)/oo/3.

175 William Nagel v. The Czech Republic, scC Case No. 049/2002; Nykomb Synergetics Technology Holding AB v. The Republic of Latvia, sCC; CCL v. Republic of Kazakhstan, sCC Case No. V 122/20o1; Anatolie Stati, Gabriel Stati, Ascom Group SA and Terra Raf Trans Traiding Ltd v. Kazakhstan, scc Case No. v 116/2010.

176 OKKV $(O K K B)$ and others v. Kyrgyz Republic; Lee John Beck and Central Asian Development Corporation v. Kyrgyz Republic. 


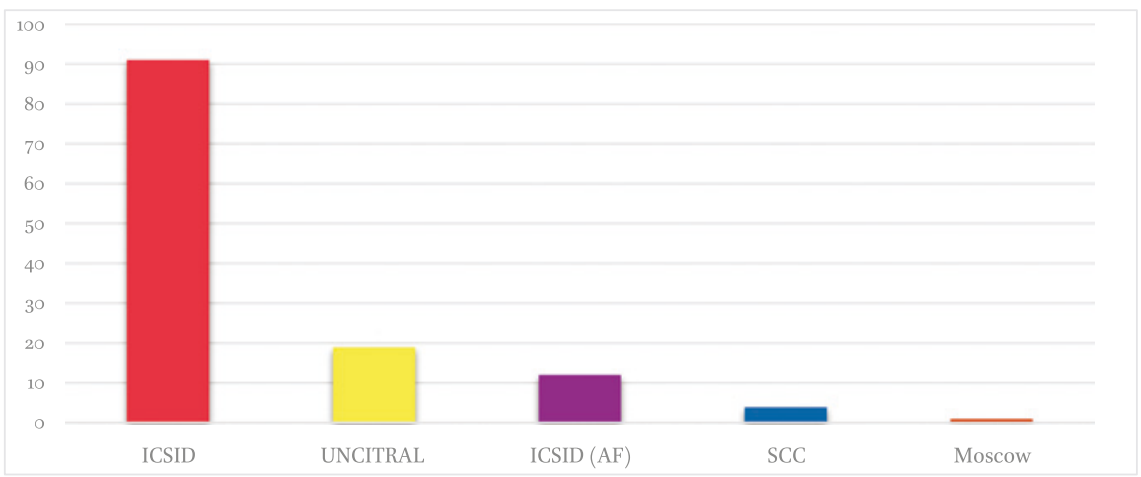

FIGURE 1 Arbitration rules in cases with elements of contract interpretation in investment treaty arbitration

The figure above summarises the frequency of arbitration rules used in the analysed cases. It may be interesting to observe that the frequency of use of arbitration rules in the cases with contract interpretation by and large reflects the frequency of the use of arbitration rules generally in investment treaty arbitration with the ICSID and the SCC Arbitration Institute being among the most used institutions and the UNCITRAL Arbitration Rules being among the most used for ad hoc arbitration. ${ }^{177}$ Other arbitration rules, which are not applicable in the analysed cases with elements of contract interpretation, can appear in some other new cases.

The cases with contract interpretation which are not conducted under the delocalised (ordinary) ICISD Arbitration Rules all have a seat. These are the proceedings under the ICSID Additional Facility Rules, the UnCITRAL Arbitration Rules, the sCC Arbitration Rules, and the MCCI Arbitration Rules. The chosen seats were in Washington (mostly for the ICSID Additional Facility Rules), ${ }^{178}$ Paris, ${ }^{179}$

177 Kaj Hobér, 'Investment Treaty Arbitration and Its Future - If Any', 7 (2015) Yearbook of Arbitration and Mediation 58 .

178 Crystallex International Corporation v. Bolivarian Republic of Venezuela, ICsid Case No. $\mathrm{ARB}(\mathrm{AF}) / 11 / 2 ;$ Gemplus S.A., SLP S.A., Gemplus Industrial S.A. de C.V.v. The United Mexican States, ICSID Case No. ARB(AF)/04/3; National Grid plc v. The Argentine Republic; Talsud S.A. v. The United Mexican States, ICSID Case No.ARB(AF)/o4/4; Vannessa Ventures Ltd. v. Bolivarian Republic of Venezuela, ICSID Case No. ARB(AF) O4/6; Waste Management, Inc. v. United Mexican States ("Number 2"), ICSID Case No. ARB(AF)/oo/3; AWG Group Ltd. v. The Argentine Republic.

179 Anglo American PLC v. Bolivarian Republic of Venezuela, ICSID Case No. ARB(AF)/14/1; Energoalians TOB v. Republic of Moldova; Khan Resources Inc., Khan Resources B.V., and Cauc Holding Company Ltd.v. The Government of Mongolia; MNSS B.V. and Recupero Credito 
The Hague, ${ }^{180}$ Stockholm, ${ }^{181}$ Geneva, ${ }^{182}$ London, ${ }^{183}$ Brussels, ${ }^{184}$ Toronto, ${ }^{185}$ Singapore ${ }^{186}$ and Moscow. ${ }^{187}$ The figure below summarises the information on the seats chosen.

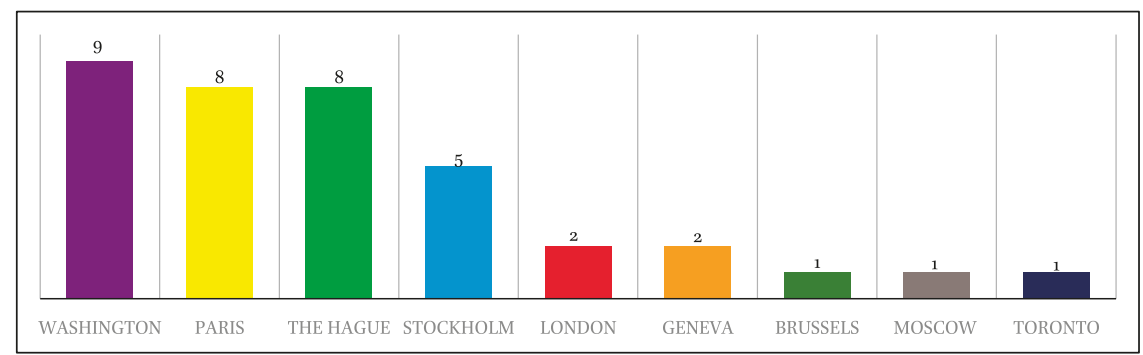

FIGURE 2 Seats in cases with elements of contract interpretation in investment treaty arbitration

Acciaio N.V.v. Montenegro, ICSID Case No. ARB(AF)/12/8; Nova Scotia Power Incorporated v. Bolivarian Republic of Venezuela, ICSID Case No. ARB (AF)/11/1; Oxus Gold v. Republic of Uzbekistan; Peter Franz Vocklinghaus v. Czech Republic; Vincent J. Ryan, Schooner Capital LLC, and Atlantic Investment Partners LLC v. Republic of Poland, ICSID Case No. ARB(AF)/ $11 / 3$.

180 British Caribbean Bank Limited v. The Government of Belize, PCA Case No. 2010-18; Chevron Corporation (USA) and Texaco Petroleum Company (USA) v. The Republic of Ecuador, PCA Case No. 34877; Chevron Corporation and Texaco Petroleum Corporation v. The Republic of Ecuador, PCA Case No. 2009-23; Flemingo DutyFree Shop Private Limited v the Republic of Poland; Sergei Paushok, CJSC Golden East Company and CJSC Vostokneftegaz Company v. The Government of Mongolia; ST-AD GmbHv. Republic of Bulgaria, PCA Case No. 2011-o6; Ulysseas, Inc. v. The Republic of Ecuador, PCA Case No. 2009-19.

181 Anatolie Stati, Gabriel Stati, Ascom Group SA and Terra Raf Trans Traiding Ltdv. Kazakhstan, SCC Case No. v 116/2010; CCL v. Republic of Kazakhstan, SCC Case No. v 122/2001; Luigiterzo Bosca v. Lithuania, PCA Case No. 2011-05; Nykomb Synergetics Technology Holding ABv. The Republic of Latvia; William Nagelv. The Czech Republic, scC Case No. 049/2002.

182 Saluka Investments B.V.v. The Czech Republic; Werner Schneider, acting in his capacity as insolvency administrator of Walter Bau Ag (In Liquidation) $v$. The Kingdom of Thailand.

183 Occidental Exploration and Production Company v. The Republic of Ecuador, LCIA Case No. UN3467; Ronald S. Lauder v. The Czech Republic, UnCITRAL; David Minnotte \& Robert Lewis $v$. Republic of Poland, ICSID Case No. ARB (AF)/10/1.

184 Eureko B.V.v. Republic of Poland.

185 Mercer International Inc. v. Government of Canada, ICSID Case No. ARB (AF)/12/3.

186 Lao Holdings N.V.v. Lao People's Democratic Republic, ICSID Case No. ARB(AF)/12/6.

187 Lee John Beck and Central Asian Development Corporation v. Kyrgyz Republic, Arbitration at the Moscow Chamber of Commerce Case No. A-2013/o8. 


\subsection{Patterns for Contract Interpretation}

Tribunals' reasoning, evidencing attempts to ascertain the content of contractual provisions, may be better understood if allocated into groups of repeatedly exercised approaches, or patterns. Many ways exist to classify these patterns. One of the possibilities, for instance, is to single out the patterns in light of how theory and philosophy of law approach legal argumentation and justification. If one employs Robert Alexy's classification of external legal justification, the interpretative efforts of treaty-based tribunals in relation to contracts may be captured through categories of [proper] interpretation, dogmatic argumentation, the use of precedents and empirical reasoning. ${ }^{188}$ If one applies Joxerramon Bengoetxea's perspective, one can distinguish between literal arguments, systemic arguments and common sense arguments invoked by tribunals in their interpretation of contracts. ${ }^{189}$ Another possibility is to identify interpretative patterns depending on the interpretative challenges within a contract which treaty-based tribunals have to solve in the framework of a given case. This could lead to distinguishing between interpretations exercised in relation to ambiguous, vague, insufficient or silent contractual provisions..$^{190}$

188 For Alexy's classification of legal reasoning see Robert Alexy, A Theory of Legal Argumentation. The Theory of Rational Discourse as Theory of Legal Justification (Oxford University Press 1989) 261-36o. According to Alexy, external justifications deal with the soundness and validity of inferences in the internal logical reasoning and the soundness of premises upon which it is based. Of the six forms for external justification which Alexy names, four receive most frequent expression in the patterns of disengagement from national law in relation to contract interpretation in the reasoning of the Permanent Court of Justice (PCIJ), the International Court of Justice (ICJ), the European Court of Human Rights (ECtHR), the Iran-USA Claims Tribunal and in investment treaty arbitration. Relying on this work, I attempted to taxonomise reasoning in relation to the ascertainment of the content of contractual provisions exercised by international courts and tribunals through the taxonomy of external justification for legal reasoning in the paper 'Disengagement from Domestic Law in Contract Interpretation in Public International Law Context' presented at the Workshop 'Engaging with Domestic Law in International Adjudication: Fact-finding or Transnational Law-Making?' at the University of Amsterdam on 1 March 2019.

189 Joxerramon Bengoetxea, The Legal Reasoning of the European Court of Justice: Towards a European Jurisprudence (Oxford University Press 1993) 218-270.

190 Liliana E Popa, for instance, divides patterns of treaty interpretation according to the difficulties in the text being insufficiently clear, inconsequent, ambiguous, doubtful, obscure, vague or silent treaty provisions - see Liliana E Popa, Patterns of Treaty Interpretation as Anti-Fragmentation Tools: A Comparative Analysis with a Special Focus on the ECtHR, WTO and ICJ (Springer 2018) 4. On the distinction between ambiguity and vagueness, see Ralf Poscher, 'Ambiguity and Vagueness in Legal Interpretation' in Lawrence M Solan and 
There is also a possibility to identify patterns depending on obedience to or deviation from the national law applicable to a contract.

The most revealing for the purpose of this work appears to concentrate on the role of national law applicable to a contract for its interpretation. This focus assists to understand the tribunals' interpretative routines vis-à-vis what can be described as a normative standard for contract interpretation. Indeed, a proper law of contract appears as a commonly recognised, normative standard for contract interpretation similar to how the VCLT is for treaty interpretation. This perspective, featuring an adherence to national law, captures the most critical characteristics of contract interpretation as an analytical exercise in investment treaty arbitration - its normative foundation.

All 128 cases with elements of contract interpretation are accordingly divided into two principal groups: those cases in which tribunals relied on national law to understand the content of contractual provisions and those cases in which tribunals failed to rely on or deliberately choose not to rely on national law for contract interpretation. Express reliance on national law in those parts of the awards, which evidence the tribunals' efforts on ascertaining the content of contractual provisions, served as a basis for allocating the cases to one group or another. Furthermore, cases were placed in the group in which national law informed interpretative efforts if a tribunal relied at least once on national law to ascertain the content of contractual provisions. Cases, accordingly, were placed in the category without reliance on national law for contract interpretation if there was no single reference to national law in the parts evidencing the tribunals' efforts to ascertain the content of contractual provisions. The screening thus exercised was textual, based on the awards' 'surface' express references to national law, and did not go deeper in the analysis of the correctness of the application of national law in contract interpretation. ${ }^{191}$ Put differently, if an award evidenced the tribunal's express reliance on national law to ascertain the content of contractual provisions, even an abbreviated one, the case appears in the category with application of national law regardless of possible mistakes and failures in its application.

Despite being somewhat superficial in character, the overview nevertheless represents a valuable general indication of the positions that treaty-based tribunals take in relation to the role of national law for contract interpretation. The allocation of cases between the two groups shows that national

Peter Tiersma (eds), The Oxford Handbook of Language and Law (Oxford University Press 2012) 128-145.

191 For a more nuanced critical look at the application and non-application of national law to contract interpretation, see Chapter 4 of this work. 
law did not inform the tribunals' interpretative efforts in a significant number of cases $-47 \%$ of all cases with elements of contract interpretation (or $128-12-56=6$ o cases). Tribunals accordingly relied upon national law to various extents in their efforts to ascertain the content of contractual provisions in the majority of cases $-53 \%$ of the cases (or $12+56=68$ cases). ${ }^{192} \mathrm{~A}$ closer look at the cases shows, however, more reason for the discomfort associated with disengagement from national law as a normative standard for contract interpretation. Only $9 \%$ of all cases with elements of contract interpretation (or 12 cases) demonstrate tribunals' reliance on interpretative rules and principles of national law for contract interpretation (Annex v). ${ }^{193}$ The predominant portion of cases with reliance on national law (56 cases) shows that national law appeared merely as a background law. ${ }^{194}$ When relying on national law

192 Annex Vi and Annex V together.

193 Even if the tribunals' reasoning also demonstrates reliance on national law as a background law, so far as interpretative rules are invoked, the case was allocated to the category with application of interpretative rules for contract interpretation (Annex v) - see Accession Mezzanine Capital L.P. and Danubius Kereskedöház Vagyonkezelö Zrt. v. Hungary, ICSID Case No. ARB /12/3, Award dated 17 April 2015, para. 79; ACP Axos Capital GmbHv. Republic of Kosovo, ICSID Case No. ARB/15/22, Award dated 3 May 2018, para. 220-222; Azpetrol International Holdings B.V., Azpetrol Group B.V. and Azpetrol Oil Services Group B.V. v. The Republic of Azerbaijan, ICSID Case No. ARB/ 06/15, Award dated 8 September 2009, para. 61, 64-65, 90-91; Caratube International Oil Company LLP and Devincci Salah Hourani v. Republic of Kazakhstan, ICSID Case No. АRв/13/13, Award dated 27 September 2017, para. 6o1-61o, 658; Ceskoslovenska Obchodni Banka, A.S. v. The Slovak Republic, ICsid Case No. ARB $/ 97 / 4$, Decision of the Tribunal on Objections to Jurisdiction dated 24 May 1999, para. 50-51; Award dated 29 December 2004, para. 82-93, 113-114; Chevron Corporation and Texaco Petroleum Corporation v. The Republic of Ecuador, UnCitral, PCA Case No. 2009-23, First Partial Award on Track I dated 17 September 2013, para. 63-9o; CMS Gas Transmission Company v. The Republic of Argentina, ICSID Case No. ARB/o1/8, Award dated 12 May 2005, para. 221; Daimler Financial Services AG v. Argentine Republic, ICSID Case No. ARB/ 05/1, Award dated 22 August 2012, para. 133; Gambrinus, Corp. v. Bolivarian Republic of Venezuela, ICSID Case No. ARB/11/31, Award dated 15 June 2015, para. 260, 265; Decision on Annulment dated 3 October 2017, para. 52-53, 141, 180-181, 186-187, 216218; Lao Holdings N.V. v. Lao People's Democratic Republic, ICSID Case No. ARB(AF)/12/6, Interim Ruling on Issues Arising Under the Deed of Settlement dated 19 December 2014, para. 74, 91, 102-103, 114-115, fn 35-38; Perenco Ecuador Ltd. v. The Republic of Ecuador and Empresa Estatal Petróleos del Ecuador (Petroecuador), ICsid Case No. ARB/ o8/6, Decision on Remaining Issues of Jurisdiction and on Liability dated 12 September 2014, para. 326, 356-359; William Nagel v. The Czech Republic, scc Case No. 049/2002; Final Award dated 9 September 2003, para. 68, 104, 228.

194 Provided that the parties agree on the relevance of national law for contract interpretation, they rarely, in fact, dispute the content of the interpretative provisions of national contract laws. Furthermore, it is not unusual for treaty-based tribunals, as a result, to report that both parties are in agreement on the content of interpretative rules. Parties disagree, however, typically on the application of these rules to particular facts. See, for 
as a background law, tribunals regarded it as supplementing understanding of an individual contractual term, ${ }^{195}$ for understanding certain (larger) parts of the contract which incorporated the elements of the statutory provisions verbatim ${ }^{196}$ or became 'the particularized versions of the principles' specified in various legislative acts ${ }^{197}$ to understand the content of the parties' mutual undertakings given in the context of the general civil or commercial law regulation, ${ }^{198}$ and to understand the content of the parties' specific mutual undertakings given in the context of the specialised legislature relating to publicprivate contracting (concessions, tender/bidding, privatisation) or to industry specialised areas (construction, broadcasting, banking, etc.). ${ }^{199}$

instance, in ACP Axos Capital GmbH v. Republic of Kosovo the tribunal noted that it was beyond dispute between the parties that the post-contractual conduct of the parties was relevant for contract interpretation under Kosovar law - ACP Axos Capital GmbH v. Republic of Kosovo, ICSID Case No. ARB/15/22, Award of 3 Mary 2018, para. 220; in Gambrinus Corp. v. Bolivarian Republic of Venezuela, the tribunal noted ' $[b]$ oth Parties and their legal experts have made reference to the rules of contract interpretation of Venezuelan law reaching however different conclusions.' - see Gambrinus Corp. v. Bolivarian Republic of Venezuela, ICSID Case No. ARB/11/31, Award dated 15 June 2015, para. 265. For the role of background law for contract interpretation and for examples of some scholarship featuring the role of background law, see the next chapter.

195 For instance, the term 'in caso d'uso' in the office lease agreement - see Hussein Nuaman Soufraki v. The United Arab Emirates, ICSID Case No. ARB/ o2/7, Decision of the Ad Hoc Committee on the Application for Annulment of Mr. Soufraki dated 5 June 2007, para. 101-102.

196 For instance, the Broadcasting Agreement in Accession Mezzanine Capital L.P. and Danubius Kereskedohaz was concluded between the National Radio and Television Board and Országos Kereskedelmi Rádió Részvénytársaság. It incorporated certain elements of the Hungarian Media Law - see Accession Mezzanine Capital L.P. and Danubius Kereskedöház Vagyonkezelö Zrt. v. Hungary, ICsid Case No. ARB/12/3, Award dated 17 April 2015, para. 77-107.

197 AWG Group Ltd.v. The Argentine Republic, UnCITRAL, Decision on Liability dated 30 July 2010, para. 99.

198 Set-off regulation in Duke Energy Electroquil Partners \& Electroquil S.A. v. Republic of Ecuador, ICSID Case No. ARB/ o4/19, Award dated 18 August 2008, para. 238-242.

199 For instance, in ACP Axos Capital GmbH v. Republic of Kosovo, ICsID Case No. ARB/15/22, to understand whether a binding contract came into existence as a result of the bidding process, the tribunal had to understand the exchanges between the parties against the normative regulation of the bidding procedure in the Republic of Kosovo. The tribunal shared the position of an expert on public law who explained the relevance of three laws (Law No. 03/L-087 on Publicly Owned Enterprises, Law No. 04/L-045 on Public-Private Partnership, and Law No. 04/L-042 on Public Procurement) for the decision and decided to apply all three within their respective scope together with the Law on Obligations - see ACP Axos Capital GmbH v. Republic of Kosovo, ICsid Case No. ARB/15/22, Award dated 3 May 2018, para. 208-211. In Chevron Corporation and Texaco Petroleum Corporation v. The Republic of Ecuador, to ascertain the content and effect of the settlement agreement the 
To understand what this $9 \%$ in fact means, one can draw an analogy with treaty interpretation and imagine a situation in which only $9 \%$ of cases with treaty interpretation evidence the application of interpretative provisions of Articles $31-33$ of the VCLT. This number would appear far beyond what one would normally expect from the proper approach to treaty interpretation. Similarly, $9 \%$ of cases relying on interpretative rules or principles of national law applicable to contract is far beyond what one would normally expect in relation to the proper methodological approach to contract interpretation.

This $9 \%$ is also indicative of the scarcity of instructive pronouncements on the tribunals' power to interpret contracts and of a proper methodology of contract interpretation in the awards. This is again in contrast to a general recognition of a power to interpret treaties or routine acknowledgement of the role of Articles 31-33 of the VCLT for treaty interpretation in investment treaty arbitration. Regarding clarification of the mandate of treaty-based tribunals in relation to contract interpretation, one may find useful guidance only in a limited number of cases. For instance, in Laos Holdings N.V.v. The Lao People's Democratic Republic the tribunal specified that ' $[t]$ he power to apply a provision in a contract necessarily implies the power to interpret that provision'. ${ }^{200}$ In William Nagel $v$. The Czech Republic, the tribunal expressly affirmed that: ' $[a] n$ incidental need to interpret an instrument under domestic law cannot exclude the Arbitral Tribunal's jurisdiction', further specifying that '[i]f it did, virtually every similar tribunal would also be denied jurisdiction. Few, if any, investment disputes do not require the interpretation of agreements entered into under domestic law'.201 In Azpetrol International Holdings B.V., Azpetrol Group B.V., and Azpetrol Oil Services Group B.V. v. Republic of Azerbaijan the tribunal helpfully distinguished contract interpretation under national law (English law)

tribunal had to consider Article 19-2 of the Ecuadorian Constitution in force at the time of the conclusion of the settlement agreement - see Chevron Corporation and Texaco Petroleum Corporation v. The Republic of Ecuador, PCA No.20o9-23, First Partial Award on Track I dated 17 September 2013, para. 98-107; in CMS Gaz Transmission Company v. The Republic of Argentina the tribunal had to decide on the relevance of the Gas Law, the Gas Decree and the Convertibility law for interpretation of the concession - see CMS Gas Transmission Company v. The Argentine Republic, ICsid Case No. ARB/o1/8, Award dated 12 May 2005, para. 127-138. In AWG Group Ltd. v. The Argentine Republic, the concession set a hierarchy of specific legal acts relevant for its interpretation - see AWG Group Ltd. v. The Argentine Republic, UnCITRAL, Decision on Liability dated 30 July 2010, para. 98.

200 Laos Holdings N.V.v. The Lao People's Democratic Republic ICSID Case No ARB (AF) 12/6, Interim Ruling on Issues Arising Under the Deed of Settlement dated 19 December 2014, para. 66.

201 William Nagel v. The Czech Republic, scc Case No 049/2002, Award dated 9 September 2003, para. 123 . 
from treaty interpretation under international law. ${ }^{202}$ These valuable clarifications of the methodological aspects of contract interpretation have not gained weight in the reasoning for other tribunals and have not been referred.

Further, expressly endorsing the relevance of national law to contract interpretation does not ensure its proper application. One may raise questions about the adequacy of the ascertainment of national law, or in other words, ask whether the tribunals properly consider the content of relevant national law while interpreting contracts. To illustrate, it appears that the tribunal in Garanti Koza LLPv. Turkmenistan, ${ }^{203}$ while refusing to consider the relevance of the existent practice in the construction industry in Turkmenistan in regard to predicting and reporting the cost of construction work and assessing their value (so-called 'SMETA'), failed to consider that business practices and trade usages were a source of civil regulation in addition to statutory provisions under Article 5 of the Civil Code of Turkmenistan. Furthermore, the tribunal did not consider that Article 357 of the Civil Code of Turkmenistan makes trade usages and 'traditions' (akin to customs) among the relevant considerations possible for 'defining parties' rights and obligations under the contract.' Above all, Article 77 of the Civil Code of Turkmenistan expressly prioritises the common will of the parties over the contractual text. These three provisions, if not necessarily leading to a different conclusion than reached by the tribunal, at least require the tribunal to explain in a more satisfactory manner the reason for not implementing certain contractual obligations. A mere acknowledgement that SMETA was not part of legislative regulation ${ }^{204}$ did not suffice for that purpose. This criticism about paying lip service to national law mirrors similar concerns in relation to the proper application of the VCLT for treaty interpretation. ${ }^{205}$

The list of national laws, which tribunals have applied at various times in relation to the ascertainment of the content of contractual provisions, in

202 Azpetrol International Holdings B.V., Azpetrol Group B.V., and Azpetrol Oil Services Group B.V.v. Republic of Azerbaijan, ICSID Case No ARB/06/15, Award dated 8 September 2009, para. 63-64.

203 Garanti Koza LLPv. Turkmenistan (ICSID Case No. ARB/11/20).

204 Ibid. para. 331.

205 See, for instance, Richard Gardiner, Treaty Interpretation (2nd edn, Oxford University Press 2016) 8; Donald M McRae, 'Approaches to the Interpretation of Treaties: The European Court of Human Rights and the Wто Appellate Body' in Stephan Breitenmoser and others, Human Rights, Democracy and the Rule of Law: Liber Amicorum Luzius Wildhaber (Nomos Verlagsgesellschaft 2007) 1407-1422; MichaelWaibel, 'Uniformity versus Specialization(2): A Uniform Regime of Treaty Interpretation?' in Christian J Tams and others (eds), Research Handbook on the Law of Treaties (Edward Elgar Publishing 2014) 376, 395, 407. 
alphabetical order, is as follows (the number of cases in footnotes demonstrates the frequency of the reliance on the national law of a particular country/state/administrative part):

- law of Argentina;206

- law of British Columbia;207

- law of Bulgaria;208

- law of Chile;209

- law of Costa Rica; ${ }^{210}$

- law of Croatia; ${ }^{211}$

- law of the Czech Republic;212

206 AWG Group Ltd. v. The Argentine Republic, UnCitral, Decision on Liability dated 30 July 2010, para. 66, 79, 98, 231; Enron Corporation and Ponderosa Assets, L.P. v. Argentine Republic, ICSID Case No. ARB /o1/3, Award dated 22 May 2007, para. 210, 213-214; Impregilo S.p.A. v. Argentine Republic, ICSID Case No. ARB/07/17, Award dated 21 June 2011, para. 324-328; Lanco International Inc. v. The Argentine Republic, ICsID Case No. ARB/97/6, Preliminary Decision: Jurisdiction of The Arbitral Tribunal dated 8 December 1998, para. 18-19, 26; National Grid plc v. The Argentine Republic, UnCitral, Award dated 3 November 2008, para. 117-124; Urbaser S.A. and Consorcio de Aguas Bilbao Bizkaia, Bilbao Biskaia Ur Partzuergoa v. The Argentine Republic, ICSID Case No. ARB/o7/26, Award dated 8 December 2016, para. 325-328, 374, 940-942; Azurix Corp. v. The Argentine Republic, ICSID Case No. ARB/o1/12, Award dated 14 July 2006, para. 255-261; EDF International S.A., SAUR International S.A. and León Participaciones Argentinas S.A. v. Argentine Republic, ICSID Case No. ARB/o3/23, Award dated 11 June 2012, para. 943-969; CMS Gas Transmission Company v. The Republic of Argentina, ICSID Case No. ARB/o1/8, Award dated 12 May 2005, para. 205-227; Hochtief AG v. The Argentine Republic, ICsID Case No. ARB / O7/31, Decision on Liability dated 29 December 2014, para. 192.

207 Mercer International Inc. v. Government of Canada, ICSID Case No. ARB(AF)/12/3, Award dated 6 March 2018, para. 3.82-3.84.

208 Plama Consortium Limited v. Republic of Bulgaria, ICSID Case No. ARв/о3/24, Award dated 27 August 2008, para. 101, 105, 197, 199-200, 267.

209 MTD Equity Sdn. Bhd. and MTD Chile S.A. v. Republic of Chile, ICSID Case No. ARB/o1/7, Award dated 25 May 2004, para. 187-189, Decision on Annulment dated 21 March 2007, para. $73^{-75}$.

210 Reinhard Unglaube v. Republic of Costa Rica, ICsid Case No. ARB/og/20, Award dated 16 May 2012, para. 118, 170, 189-19o, 287.

211 Georg Gavrilovic and Gavrilovic d.o.o. v. Republic of Croatia, ICSID Case No. ARB/12/39, Award dated 25 July 2018, para. 458-462, 850-855.

212 Ceskoslovenska Obchodni Banka, A.S. v. The Slovak Republic, ICsID Case No. ARB/97/4, Award dated 29 December 2004, para. 68, 72, 82-95, 113-114; William Nagel v. The Czech Republic, scc Case No. 049/2002, Award dated 9 September 2003, para. 308, 315-320; Ronald S. Lauderv. The Czech Republic, UnCitral, Final Award dated 3 September 2001, para. 265-274; Peter Franz Vocklinghaus v. The Czech Republic, Award dated 19 September 2011, para. $160-165$. 
- law of Ecuador;213

- law of Egypt; ${ }^{214}$

- law of England and Wales; ${ }^{215}$

- law of Grenada; ${ }^{216}$

- law of Guatemala; ${ }^{217}$

- law of Germany; ${ }^{218}$

213 Chevron Corporation and Texaco Petroleum Corporation v. The Republic of Ecuador, UnCitral, PCA Case No. 2009-23, First Partial Award on Track I dated 17 September 2013, para. 62-63, 72, 84-85, 9o, 96-97, 10o; Perenco Ecuador Ltd. v. The Republic of Ecuador and Empresa Estatal Petróleos del Ecuador (Petroecuador), ICsid Case No. ARB/o8/6, Decision on Jurisdiction dated 30 June 2011, para. 142-146; Decision on Remaining Issues of Jurisdiction and on Liability dated 12 September 2014, para. 358, 369, 375; Burlington Resources Inc. v. Republic of Ecuador, ICSID Case No. ARB/o8/5, Decision on Liability dated 14 December 2012, para. 308-310; Chevron Corporation (USA) and Texaco Petroleum Company (USA) v. The Republic of Ecuador, UnCITRal, PCA Case No. 34877, Partial Award on the Merits dated 30 March 2010, para. 375, 400-401, 411-412, 433, 453-454; Occidental Exploration and Production Companyv. The Republic of Ecuador, LCIA Case No. UN3467, Final Award dated 1 July 2004, para. 98-115; Occidental Petroleum Corporation and Occidental Exploration and Production Company v. The Republic of Ecuador (II), ICSID Case No. ARB/o6/11, Award dated 5 October 2012, para. 616-644, 650; Duke Energy Electroquil Partners \& Electroquil S.A. v. Republic of Ecuador, ICSID Case No. ARB/O4/19, Award dated 18 August 2008, para. 238-244.

214 Malicorp Limited v. The Arab Republic of Egypt, ICSID Case No. ARв/08/18, Award dated 7 February 2011, para. 130; Unión Fenosa Gas, S.A. v. Arab Republic of Egypt, ICsid Case No. ARB $/ 14 / 4$, Award dated 31 August 2018, para. 9.69.

215 Azpetrol International Holdings B.V., Azpetrol Group B.V. and Azpetrol Oil Services Group B.V. v. The Republic of Azerbaijan, ICsid Case No. ARB/o6/15, Award dated 8 September 20o9, para. 49-61, 90; Ampal-American Israel Corporation and others v. Arab Republic of Egypt, ICsid Case No. ARB/12/11, Decision on Liability and Heads of Loss dated 21 February 2017, para. 312-316; Inmaris Perestroika Sailing Maritime Services GmbH and Others v. Ukraine, ICSID Case No. ARB/ 08/8, Decision on Jurisdiction dated 8 March 2010, para. 69-71, fn.49 (only excerpts of the award are available evidencing some attempts of the tribunal to find out the effect of the bareboat charter in the light of English law and Ukrainian law). According to the contractual terms, English law was applicable so far 'it does not come into contradiction with Ukrainian law (material and procedural)'. It would be interesting to see whether the case triggered discussion of the acute differences in contract interpretation under English and Ukrainian law.

216 RSM Production Corporation and others v. Grenada, ICSID Case No. ARB /10/6, ICSID Case No. ARB/10/6, Award dated 1o December 2010, para. 7.1.8 (i).

217 Railroad Development Corporation v. Republic of Guatemala, ICSID Case No. ARB/o7/23, Award dated 29 June 2012, para. 122.

218 Daimler Financial Services AG v. Argentine Republic, ICSID Case No. ARв/05/1, Award dated 22 August 2012, para. 133, 135, 137, 147-150; Peter Franz Vocklinghaus v. Czech Republic, Award dated 19 September 2011, para. $155^{-159}$. 
- law of Hungary; ${ }^{219}$

- law of Italy;220

- law of Kazakhstan; ${ }^{221}$

- law of Kosovo; 222

- law of Kyrgyzstan;223

- law of Latvia; 224

- law of Luxembourg;225

- law of Mexico;226

- law of Moldova; 227

- law of Mongolia; ${ }^{228}$

219 Accession Mezzanine Capital L.P. and Danubius Kereskedöház Vagyonkezelö Zrt. v. Hungary, ICsid Case No. ARB/12/3, Award dated 17 April 2015, para. 77-96, 108, 114; Emmis International Holding, B.V., Emmis Radio Operating, B.V., MEM Magyar Electronic Media Kereskedelmi és Szolgáltató Kft. v. The Republic of Hungary, ICSID Case No. ARB/12/ 2, Award dated 16 April 2014, para. 196-199; Vigotop Limited v. Hungary, ICsid Case No. ARB $/ 11 / 22$, Award dated 1 October 2014, para. 535-538.

220 Hussein Nuaman Soufrakiv. The United Arab Emirates, ICsid Case No. ARB / o2/7, Decision of the Ad Hoc Committee on the Application for Annulment of Mr. Soufraki dated 5 June 2007, para. 101-102.

221 Caratube International Oil Company LLP and Devincci Salah Hourani v. Republic of Kazakhstan, ICSID Case No. ARB/13/13, Award dated 27 September 2017, para. 6o1-610; CCL v. Republic of Kazakhstan, SCC Case 122/2001, Jurisdictional Award dated 2003, p. 130.

222 ACP Axos Capital GmbH v. Republic of Kosovo, ICSID Case No. ARB/15/22, Award dated 3 May 2018, para. $15^{2-156 .}$

223 Lee John Beck and Central Asian Development Corporation v. Kyrgyz Republic, Award dated 13 November 2013, para. 3.3 (sub.- para. 4).

224 Nykomb Synergetics Technology Holding AB v. The Republic of Latvia, SCC, Arbitral Award dated 16 December 2003, para. 3.7; UAB E energija (Lithuania) v. Republic of Latvia, ICSID Case No. ARB $/ 12 / 33$, Award dated 22 December 2017, para. 863 .

225 Gemplus S.A., SLP S.A., Gemplus Industrial S.A. de C.V.v. The United Mexican States, ICSID Case No. ARB (AF)/o4/3, Award dated 16 June 2010, para. 5-24, 5-28, 5-33; Talsud S.A. v. The United Mexican States, ICSID Case No. ARB(AF)/04/4, Award dated 16 June 2010, para. $5^{-}$ 24, 5-28, 5-33.

226 Gemplus S.A., SLP S.A., Gemplus Industrial S.A. de C.V.v. The United Mexican States, ICSID Case No. ARB (AF)/o4/3, Award dated 16 June 2010, para. 5-24, 5-28, 5-33; Talsud S.A. v. The United Mexican States, ICSID Case No. ARB(AF)/04/4, Award dated 16 June 2010, para. 524, 5-28, 5-33.

227 Mr. Franck Charles Arif v. Republic of Moldova, ICSID Case No. ARB $/ 11 / 23$, Award dated 8 April 2013, para. 398-420, 551-555.

228 Sergei Paushok, CJSC Golden East Company and CJSC Vostokneftegaz Company v. The Government of Mongolia, UnCITRAL, Award on Jurisdiction and Liability dated 28 April 2011, para. 529-533, 548, 60o-6o5. 
- law of New York; ${ }^{229}$

- law of Thailand;230

- law of Turkmenistan;231

- law of Oman; ${ }^{232}$

- law of Pakistan;233

- law of Paraguay;234

- law of the Philippines; ${ }^{235}$

- law of Poland;236

- law of Romania; ${ }^{237}$

- law of Turkey;;238

229 Lao Holdings N.V. v. Lao People's Democratic Republic, ICSID Case No. ARB(AF)/12/6, Interim Ruling on Issues Arising Under the Deed of Settlement dated 19 December 2014, para. 74, 91, 114-118, 129-135; Occidental Petroleum Corporation and Occidental Exploration and Production Companyv. The Republic of Ecuador (II), ICSID Case No. ARB /o6/11, Award dated 5 October 2012, para. 195, 616, 645-648, 65 o.

230 Werner Schneider, acting in his capacity as insolvency administrator of Walter Bau Ag (In Liquidation) v. The Kingdom of Thailand, UNCITRAL, Award dated 1 July 2009, para. 7.6.-7.13.

231 Adem Dogan v. Turkmenistan, ICsid Case No. ARB/o9/9, Decision on annulment dated 15 January 2016, para. 132, 265; Garanti Koza LLPv. Turkmenistan, ICSID Case No. ARB/11/ 20, Award dated 19 December 2016, para. 150, 288, 331.

232 Adel A Hamadi Al Tamimi v. Sultanate of Oman, ICsid Case No. ARB/11/33, Award dated 3 November 2015, para. 298-312.

233 Karkey Karadeniz Elektrik Uretim A.S. v. Islamic Republic of Pakistan, ICSID Case No. ARB/ 13/1, Award dated 22 August 2017, para. 69o-698.

234 SGS Société Générale de Surveillance S.A. v. The Republic of Paraguay, ICSID Case No. ARB/ 07/29, Award dated 10 February 2012, para. 104, 108; Bureau Veritas, Inspection, Valuation, Assessment and Control, BIVAC B.V.v. The Republic of Paraguay, ICSID Case No. ARB/o7/9, Decision of the Tribunal on Objections to Jurisdiction dated 29 May 2009, para. 85-92.

235 Fraport AG Frankfurt Airport Services Worldwide v. Republic of the Philippines (II), ICSID Case No. ARB/11/12, Award dated 10 December 2014, para. 428-468; the tribunal finding the claim under umbrella clause inadmissible nevertheless engaged into a limited ascertainment of exclusive jurisdictional clause and its effect under national law in SGS Société Générale de Surveillance S.A. v. Republic of the Philippines, ICsid Case No. ARB/ 02/6, Decision of the Tribunal on Objections to Jurisdiction dated 29 January 2004, para. 136-138.

236 Flemingo DutyFree Shop Private Limited v the Republic of Poland, UnCITral, Award dated 12 August 2016, para. 470, 476-478, 591.

237 EDF (Services) Limited v. Romania, ICSID Case No. ARB/o5/13, Award dated 8 October 2009, para. 240-269; Noble Ventures, Inc. v. Romania, ICSID Case No. ARB/o1/11, Award dated 12 October 2005, para. 114.

238 PSEG Global, Inc., The North American Coal Corporation, and Konya Ingin Electrik Üretim ve Ticaret Limited Sirketi v. Republic of Turkey, ICSID Case No. ARB/02/5, Decision on Jurisdiction dated 4 June 2004, para. 85-89, 97. 
- law of Ukraine;239

- law of Venezuela ${ }^{240}$

The cases $(47 \%$ or 6 o cases) where tribunals have not relied on national law are not uniform. In addition to the dominant group of autonomous contract interpretation uninformed by any external justification, ${ }^{241}$ one can distinguish cases in which the tribunals understood contracts in light of international law or its specific doctrines ${ }^{242}$ and in light of transnational law. ${ }^{243}$ When not relying on national law as the applicable law for contract interpretation, tribunals can also represent their analytical efforts as fact-finding. ${ }^{244}$

Despite the visibility of heterogeneity in patterns for understanding the content of contractual provisions, all the analysed cases have two common denominators. Firstly, similarities can be found in what the tribunals were looking at when they had to understand the contracts. While the investigation could be

239 Alpha Projektholding GmbH v. Ukraine, ICsid Case No. ARB/o7/16, Award dated 8 November 2010, para. 439-440; Energoalians TOB v. Republic of Moldova, UNCITRAL, Arbitral Award dated 23 October 2013, para. 193-194, 199.

240 Gambrinus, Corp. v. Bolivarian Republic of Venezuela, ICSID Case No. ARB/11/31, Award dated 15 June 2015, para 255-256, 265; Decision on Annulment dated 3 October 2017, para. 141; Anglo American PLC v. Bolivarian Republic of Venezuela, ICSID Case No. ARB (AF)/14/1, Award dated 18 January 2019, para. 335-337, 344-347, 351-355.

241 For instance, Bayindir Insaat Turizm Ticaret Ve Sanayi A.S. v. Islamic Republic of Pakistan, ICSID Case No. АRв/03/29, Award dated 27 August 2009, para. 252-256, 368-373; David Minnotte \& Robert Lewis v. Republic of Poland, ICSID Case No. ARB (AF)/10/1, Award dated 16 May 2014, para. 172-178; Suez, Sociedad General de Aguas de Barcelona, S.A. and Vivendi Universal, S.A. v. Argentine Republic (II), ICSID Case No. ARв/o3/19, Award dated 9 April 2015, para. 42-43; Gustav F W Hamester GmbH \& Co KG v. Republic of Ghana, ICsid Case No. ARB/o7/24, Award dated 18 June 2010, para 212-217, 263-266; Biwater Gauff (Tanzania) Ltd. v. United Republic of Tanzania, ICSID Case No. ARB/ 05/22, Award dated 24 July 2008, para. 495-496, 631-65o; M.C.I. Power Group L.C. and New Turbine, Inc. v. Republic of Ecuador, ICSID Case No. ARB/o3/6, Award dated 31 July 2007, para. 253-28o.

242 For instance, CMS Gas Transmission Company v. The Republic of Argentina, ICsid Case No. ARB/o1/8, Award dated 12 May 2005, para. 151; AES Summit Generation Limited and AES-Tisza Erömü Kft v. The Republic of Hungary, ICSID Case No. ARB/o7/22, Award dated 23 September 2010, para. 9.3.25, 9.3.31; Ionannis Kardassopoulos v. Georgia, ICsID Case Nos. ARB / $05 / 18$ and ARB / 07/15, Award dated 3 March 2010, para. 477-485; Ron Fuchs v. The Republic of Georgia, ICSID Case No. ARB/ 07/15, Award dated 3 March 2010, para. 477-485; Desert Line Projects LLC $v$. The Republic of Yemen, ICsid Case No. ARB / 05/17, Award dated 6 February 2008, para. 145-194.

243 For instance, Joseph Charles Lemire v. Ukraine, ICsID Case No. ARB/o6/18, Decision on Jurisdiction and Liability dated 14 January 2010, para. 109-111.

244 For instance, Bayindir Insaat Turizm Ticaret Ve Sanayi A.S. v. Islamic Republic of Pakistan, ICSID Case No. ARB/o3/29, Award dated 27 August 2009, para. 135, 458; Murphy Exploration \& Production Company International v. Republic of Ecuador, PCA Case No. 2012-16 (formerly AA 434), Partial Final Award dated 6 May 2016, para. 361. 
either detailed or more concise, tribunals as a rule did not deal with contracts as they would with other documentary evidence. Rather, they looked at the normative content of contracts as legal texts and not just as texts. Such an ascertainment of the normative meaning of legal texts is traditionally referred to as legal interpretation. ${ }^{245}$ Tribunals were not so interested to see what the texts said as such; they were rather more interested in what the texts meant. In addressing or relying upon contractual provisions, treaty-based tribunals accordingly engaged in contract interpretation. Secondly, similarities can be found in the way tribunals attempted to understand contracts. If seen on a subjective-objective spectrum, the prevailing approach towards understanding the content of contractual provisions in investment treaty arbitration tends to be more objective than subjective. Even when subjective intent had to be investigated because of the chosen methodology, tribunals gave weight to post-contractual conduct and other objective confirmations of the proper contractual meaning. The fact that parties in the arbitral proceedings, on frequent occasions, were not precisely the same parties to the contracts at stake, also explains the preference for objectivity and frequent textualism. ${ }^{246}$ Furthermore and connected to the above, an objective approach benefits from further reinforcement by the fact that disputes in investment treaty arbitration do not hinge as a rule upon the direct enforcement of the contractual rights between the parties. ${ }^{247}$

\subsection{Conclusion}

Treaty-based tribunals interpret a broad range of contractual provisions which are part of rather divergent contractual arrangements. The purposes of their

245 For instance, Aharon Barak, Purposive Interpretation in Law (Sari Bashi trans., Princeton Univ. Press 2005) 3 .

246 In this context, it is interesting to observe some similarity between an objectivity in contract interpretation in investment treaty arbitration and an approach taken in the Draft of Common Frame of Reference (DCFR) for contract interpretation that directly emphasises the necessity to interpret the contract objectively when an issue at stake relates to the rights of third parties (Book II, Article II. - 8:101(3)(b): 'The contract is, however, to be interpreted according to the meaning which a reasonable person would give to it: [...] (b) if the question arises with a person not being a party to the contract or a person who by law has no better rights than such a party, who has reasonably and in good faith relied on the contract's apparent meaning.'

247 Somewhat exceptionally, an umbrella clause can be viewed as enforcing contractual undertakings through the treaty standard of investment protection. Importantly, the enforcement thus exercised is not direct but rather through the standard of investment protection. 
interpretative efforts reflect investment treaty arbitration from top to bottom: jurisdiction, attribution, violation of standards of investment protection, compensation, etc. And while noticeable in approximately $53 \%$ of awards with elements of contract interpretation, national law has not secured a dominant methodological position. Only $9 \%$ of cases demonstrate reliance on interpretative rules and principles of national law.

The empirical observations revealed here may lead to various avenues of further research. It may be interesting to concentrate on the specific types of contractual arrangements which treaty-based tribunals have to ascertain. It may be promising to look at differences in approaches to the interpretation of various contractual clauses. It may be informing to contrast contract interpretation exercised in different procedural settings of investment treaty arbitration whilst differentiating between ICSID and non-ICSID arbitration. It may be engaging to verify potential implications which different substantive regimes of IIAs might have for contract interpretation. It may be enlightening to contrast contract interpretation exercised for jurisdictional purposes with contract interpretation exercised for the merits of a treaty claim. All of these, as well as many other aspects identified in this chapter, are potentially rewarding. They advance understanding of interpretative preferences in interrelationships with interpretative material, interpretative occasions, and procedural frameworks. However, neither of these directions for research directly clarify the second research question that remains to be answered in this work, regarding how treaty-based tribunals should interpret contracts. This will be explored in the next chapters. 
Yuliya Chernykh - 9789004414709

Downloaded from Brill.com04/26/2023 01:49: 03PM via free access 